\title{
OPERATORS’ AND PROCESSORS’ LIENS: PRIORITY, ENFORCEMENT, AND PRACTICAL CONSIDERATIONS
}

\author{
EDWARD A. LEEW ${ }^{*}$ AND ZEKE PURVES-SMITH**
}

This article discusses the consequences of nonperfection of an Operator's lien and the casual attitude of Operators towards protecting their security interests. The authors also discuss the nature and level of protection provided by a valid Operator's lien in a variety of circumstances, and a number of enforcement considerations, from both a practical and legal perspective, in both a perfected and non-perfected context.
Cet article discute les conséquences causées par l'imperfection du lien opérationnel et de l'attitude décontracté des opérateurs envers la protection de leurs intérêts sécuritaires. Les auteurs discutent aussi la nature et le niveau de protection que donne un lien opérationnel valide dans de diverses circonstances, et discutent de considérations d'exécutions d'une perspective pratique et légale dans un contexte parfait et imparfait.

\section{TABLE OF CONTENTS}

I. INTRODUCTION . . . . . . . . . . . . . . . . . . . . . . . . . . . . . . . . . . . . 298

II. GetTING STARTED . . . . . . . . . . . . . . . . . . . . . . 298

III. UNDERLYING PREMISES - A CURRENT APPROACH . . . . . . . . 300

A. The JoINT PROPERTY IS COMPRISED OF A COMBINATION OF ESTATES IN DIFFERENT TYPES OF BOTH REAL

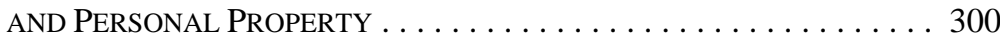

B. THE CAPL OPERATOR'S LIEN IS PRIMARILY A CONTRACTUAL LIEN GOVERNED BY A COMPREHENSIVE STATUTORY REGISTRATION SCHEME . . . . . . . . . . . . . . . . . . 301

C. The Practical IMPORTANCE of THE CAPL Lien $\ldots \ldots \ldots \ldots 303$

IV. REMEDIES AND ENFORCEMENT . . . . . . . . . . . . . . . . . 303

A. The Enforcement Process $\ldots \ldots \ldots \ldots \ldots \ldots \ldots \ldots \ldots \ldots \ldots$

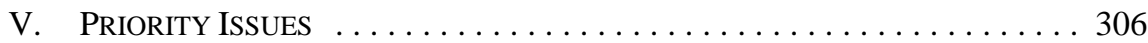

A. The CurRent RelevanCE OF COMMON LAW AND

EQUiTABLE PRIORITY RULES TO OPERATORS’ LIENS . . . . . . . . . 306

B. The StATUTORY PRiORITY SCHEME $\ldots \ldots \ldots \ldots \ldots \ldots \ldots$

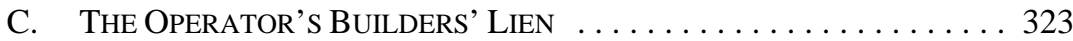

D. SUBORDINATION . . . . . . . . . . . . . . . . . . . . . . . . 324

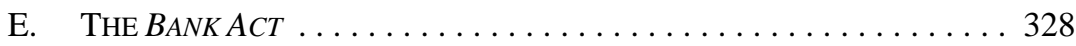

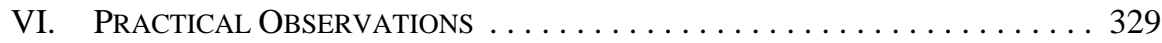

A. To Register or Not To Register . . . . . . . . . . . . . . 329

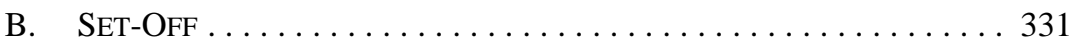

C. Questionable End Runs AND SHORTCUTS . . . . . . . . . . . . . 334

D. Other PRACTICAL ObSERVATIONS . . . . . . . . . . . . . . . . . . . 337

VII. PROCESSORS' LIENS . . . . . . . . . . . . . . . . . . . . . . . 342

VIII. CONCLUSIONS AND RECOMMENDATIONS . . . . . . . . . . . . . . . . 344

* $\quad$ Partner, Oil \& Gas, Regulatory and Corporate Commercial, McMillan LLP, Calgary, Alberta. Associate, Oil \& Gas, Regulatory and Corporate Commercial, McMillan LLP, Calgary, Alberta. 


\section{INTRODUCTION}

An Operator ${ }^{1}$ almost always advances its own money to pay all costs and expenses incurred for the joint account, including all taxes with respect to property held for the joint account. In fact, an Operator is specifically required to do so, by several clauses of the 1990 CAPL Operating Procedure, including cls. 306, 312, and 502. ${ }^{2}$ The 1990 CAPL does not provide for a release from or suspension of that requirement in any circumstances. That is to say, even if the Joint-Operator is in arrears, fails to provide security, or pay a cash call under cl. 503, the Operator must continue to advance money where expenditures are necessary or have been authorized. ${ }^{3}$

When an Operator pays costs and expenses under that provision, it is lending money to its Joint-Operators. The 1990 CAPL secures the Operator in respect of those loans by giving the Operator a lien over all of the several types of property that are involved in an oil or gas property. ${ }^{4}$ However, the priority and effectiveness of that security are very dependent on facts. Almost universally, Operators do not take advantage of the registrations that are available to them in order to perfect that security.

What are the consequences of non-registration? Why are Operators so casual about protecting their security? In this article, we will explore those questions as well as the nature and level of protection that is afforded to an Operator by an Operator's lien in a variety of circumstances, even when it is registered, from both a legal and practical perspective. Although the Canadian Association of Petroleum Landmen (CAPL) came out with a new and improved Operating Procedure in 2007, ${ }^{5}$ we will focus exclusively (with some minor comparative notes) on the 1990 CAPL, as the 2007 CAPL is not yet in general use. ${ }^{6}$ Due to constraints on time and length we will focus exclusively on land and operations located in Alberta. We will also focus primarily on the Operator's perspective as opposed to that of a Joint-Operator.

\section{GETTING STARTED}

Most exploration and development companies operate at least some of their lands. Let us call one such company "Opco," and begin with a phone call that Opco might make to its lawyer. Opco advises that one of its joint venture partners, "Jointco," owes Opco a lot of money in relation to a joint property governed by the 1990 CAPL, and operated by Opco.

$1 \quad$ As defined in the 2007 CAPL Operating Procedure, cl. 1.01, s.v. "Operator," online: Canadian Association of Petroleum Landmen (CAPL) <http://www.landman.ca/landman_tools/operating procedure2007.php> [2007 CAPL] and the 1990 CAPL Operating Procedure (Calgary: Canadian Association of Petroleum Landmen, 1990) [1990 CAPL].

1990 CAPL, ibid.

Ibid., cl. 503.

Ibid., cl. 505.

2007 CAPL, supra note 1.

The attempted improvements over the 1990 CAPL are summarized in: Michael W. McCachen \& Christopher Petrucci, "How to Get Paid: Making the Most of the CAPL Operator's Lien” The Negotiator (February 2009) 2, online: CAPL <http://www.landman.ca/publications/Negotiator/2009/feb/feb09_ layout.pdf>; also in Craig Spurn, Jana Prete \& Melissa Zerebeski, "The 2007 CAPL Operating Procedure” (2009) 46 Alta. L. Rev. 427. 
Opco might say that it is not really concerned - after all, the 1990 CAPL gives Opco a first lien and charge on Jointco's interests. Opco has some ideas as to how to put pressure on Jointco and it wants to run them by its lawyer. Opco also wants to have a general conversation about the Operator's lien and how to go about enforcing it. It wants to know what it should do and when it can do it in order to begin to collect the debt that is owed to it.

As always, it is important that Opco’s lawyer learn certain critical facts in order to advise Opco properly. We hope to show you which facts are critical, and why. The legal and practical considerations relating to the registration, enforcement, and priority of a CAPL lien vary widely with the particular circumstances at play at any time. In fact, even the question of whether some or all of the various remedies provided to the Operator have any practical value in any case depends upon such variables as, for instance, the level of drilling activity at the time.

The following is a list of questions that Opco's lawyer might consider posing. These are intended to help to define Opco's current scenario for the purposes of focusing quickly on what is important, what Opco's risks, rights, and options are, and what actions Opco should take.

1. How much money does Jointco owe?

2. Has Jointco given any reasons for its non-payment? (Does it dispute the validity of any amounts charged to it, or any accounting, practice, or signature on an Authority for Expenditure (AFE)? If so, is there any merit to those objections?)

3. How material is the disputed amount of money to each of Jointco and Opco?

4. How long has Jointco owed the money to Opco?

5. Is the debt owing under one contract or several?

6. Are we dealing with the 1990 CAPL?

7. Has Opco served a valid notice of default on Jointco?

8. How much revenue are the joint properties to which the arrears relate currently producing on a monthly basis?

9. What is the current level of drilling activity on the affected lands?

10. Does Opco have other properties in common with Jointco? If so, who operates them and what is the cash flow that they generate? Are they also governed by 1990 CAPL?

11. Does Jointco take its share of production in kind? Does it do so on other commonly held properties? 
12. Does Opco owe Jointco any money?

13. What is known about Jointco's financial strength? Is it in immediate danger of falling into insolvency?

14. Has Opco cash called Jointco, or asked for security, under cl. 503 of the 1990 CAPL?

15. Describe the joint properties to which the debt relates - what are the most important components? Are there any important third party contracts or major facilities involved? Is the land Crown or freehold land?

16. Did Opco register its Operators' liens at the Personal Property Registry, the Land Titles Office, or Alberta Energy?

In addition, the lawyer will likely advise Opco that he or she would like to conduct some quick searches. The lawyer will search Jointco’s name at the Personal Property Registry to learn if Jointco's bank or any other parties have registered security that might pose a problem to Opco, as well as the most valuable joint lands that Opco and Jointco jointly own for the same reason, and it will conduct court and bankruptcy office searches for indications of the commencement of insolvency proceedings or other material proceedings. This article addresses the legal and practical analyses that flow from the answers to the foregoing inquiries, as well as a variety of other factual variables, and that form the basis of the advice that Opco needs.

\section{Underlying Premises - A Current Approach}

At the outset, we wish to set out some framework thoughts. We hope that these will give the reader a perspective on the approach that we have taken, and an understanding of some of our conclusions.

\section{A. The Joint Property is Comprised of A CoMbination of Estates in Different Types of Both Real AND Personal Property}

One of the challenges in discussing Operators' liens is the need to keep in mind that they apply to several different types of property — potentially both freehold and Crown real property interests (both as to surface and mineral rights), and a number of different types of tangible and intangible personal property, all of which together form an economic unit. ${ }^{7}$

The rights to explore for and take oil and gas provide the fundamental value, produced oil and gas and proceeds from their sale provide cash flow. But there can be no production without a wellbore, wellhead equipment, and gathering lines, and the contracts that relate to all of those assets can also be vital to the ability to capture value. The most important and valuable components are:

(a) the rights to explore for and produce oil or gas - a profit à prendre (see Berkheiser v. Berkheiser,

[1957] S.C.R. 387);

(b) the surface rights;

(c) the wellbore - probably a combination of both the surface rights and the mineral rights, and so encompassed within those "interests in land";

(d) the surface equipment - probably largely personal property, except to the extent that it might

be considered a "fixture" and part of the surface rights interests in land.

(e) the severed oil or gas that is produced - personal property; 
Different statutes and legal principles apply to different types of property. Having a first priority position on a battery, but not the underlying working interest, may provide little value and may be difficult to sell, especially when that interest in the battery is only the fractional interest of a co-owner. One should usually identify the property types that are one's focus when considering Operator's lien issues. For instance, when one analyzes the Mines and Minerals Act, ${ }^{8}$ one is looking at rules that govern only one type of interest - real property rights in mineral rights that are owned by the Crown. Those particular rules do not apply to any freehold surface or mineral rights that may also be involved in the economic unit, to the severed oil or gas that is taken from those lands, or to the proceeds of sale of that production. In this article, we will attempt to maintain a clear recognition of where we are at any time.

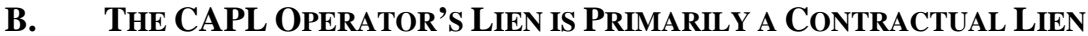 GOVERNED BY A COMPREHENSIVE STATUTORY REGISTRATION SCHEME}

We will focus primarily upon the "lien and charge" that is given to the Operator by cl. 505(a) of the 1990 CAPL and the associated remedies that are set out in cl. 505(b). ${ }^{9}$ We will refer to that lien and charge as the "CAPL lien.” But there are several other security interests that might be available to the Operator that are created by statute, common law, or equity and which are based on the relationship of the Operator to the Joint-Operators or the services that the Operator provides. We will refer to these other potential security interests as the "relationship liens." ${ }^{10}$ We will use the term "Operator's lien" to encompass both the CAPL lien and the relationship liens.

Legal writers have explored the proper characterization of the CAPL lien within the rules of the common law and equity, and the manner in which various legal and equitable rules might apply to the CAPL lien in a variety of factual scenarios. Those rules differentiate among legal, equitable, and contractual liens, and among liens, charges, and mortgages, and there are separate rules for security interests in real property and interests in personal property. ${ }^{11}$

It has been suggested that, in some circumstances, an unregistered CAPL lien might be an "equitable lien," that registered security interests are "legal interests," and that the two might compete in some circumstances on the basis of the rules of equity. If that is true, then it is critical to know how to characterize the unregistered and registered Operator's lien, and

(f) the proceeds of the sale of such produced oil or gas - personal property; and

(g) rights under a variety of contracts and government authorizations, including title, land, and production agreements, and rights to receive the proceeds of future sales of production debts choses in action and personal property.

Therefore we must consider various types of land and personal property. We must also account for the separate treatment of freehold lands, under the Land Titles Act, R.S.A. 2000, c. L-4 [LTA] and Crownowned land, under the Mines and Minerals Act, R.S.A. 2000, c. M-17 [MMA].

MMA, ibid.

1990 CAPL, supra note 1 , cls. 505(a)-(b).

We are using the term "lien" in the broadest sense.

It is interesting, at least on an academic level, to note that the CAPL lien is a "lien and charge" and not a "mortgage." We have not identified any significant practical consequences of that distinction, although we do note that the Builders' Lien Act, R.S.A. 2000, c. B-7 [BLA], subordinates builders' liens to mortgages in certain circumstances. 
the security interests with which it competes, within those rules. ${ }^{12}$ We suggest that the attempt to characterize the CAPL lien as either a legal or equitable lien or charge or mortgage is of little importance in most circumstances that one is likely to encounter. That characterization would be of significance only if it would be needed to define the remedies that the CAPL lien provides, to determine whether the CAPL lien can be registered under the applicable statutes, or to resolve a priority contest involving a CAPL lien. In most cases, the common law characterization is not needed for any of those purposes. In the end, our analysis has led us to the conclusion that neither the common law characterization of the CAPL lien nor the relationship liens (and the statutes, common law, and equitable principles that define and govern them) has any significant usefulness in most of the situations that an Operator is likely to encounter.

The CAPL lien is, simply, a contractual security interest in real and personal property, enforceable according to its terms, and registrable under and governed principally by applicable statutory priority schemes. Whether it is legal or equitable, or a lien or charge, or something else does not seem to be of major significance. Whatever it is, its remedies are clearly spelled out in the contract and almost all important priority questions relating to the CAPL lien will be answered by reference to very simple and clear statutory provisions. That seems to be true regardless of which component of the "joint lands" or various types of personal property one considers.

However, it is important to keep in mind that the Operator has access to other contractual and self-help tools for protecting its creditor's rights beyond those set out in the CAPL lien and cl. 505. Before setting out the Operator's remedies in cl. 505(b), the 1990 CAPL expressly preserves "the Operator's other rights as contained in this Operating Procedure or otherwise held at law or in equity."13 The list of remedies set out in cl. 505(b) is not intended to be exhaustive. ${ }^{14}$

Thus, after a Joint-Operator defaults, all of the Operator's rights set out anywhere in the 1990 CAPL remain intact (including such obvious provisions as cl. 503, but also such provisions as cls. 103 and 107 of the 1996 PASC Accounting Procedure ${ }^{15}$ ). In addition, we should not overlook that, in some circumstances, an Operator might wish to resort to one or more of the relationship liens.

Therefore, we have given some consideration as to whether one or more of the relationship liens might prove to be useful in a situation in which the CAPL lien remedies do not serve an Operator's specific needs, or in which the technical steps for enforcing them will cause unacceptable delays or have not been followed. In some circumstances, they may even be useful as a defence to breaching the 1990 CAPL. It is also interesting to consider whether they may be of some use in a priority dispute, such as when the statutory priority scheme

12 See generally Karen L. Pettifer, "Status of the Operator's Lien in Law and in Equity” (1987) 26 Alta. L. Rev. 87; and see William T. Corbett, "Priority Issues Affecting Operators' and Suppliers' Liens” (Paper presented to Oil and Gas Sector Conference, "Creditors’ Rights in the Petroleum Industry,” 25 April 1996) (Toronto: Insight Press, 1996).

1990 CAPL, supra note 1, cl. 505(b).

Ibid.

1996 PASC Accounting Procedure (Calgary: Petroleum Accountants Society of Canada, 1996) [1996 PASC]. 
leaves the CAPL lien in second place - for instance, might the Operator have some relationship lien that falls outside of the statutory scheme and which might hold priority over a competing lien or charge on the basis of equitable principles?

\section{THE PRACTICAL IMPORTANCE OF THE CAPL LIEN}

The Operator's CAPL lien will not always be the most valuable tool available to the Operator, and so its maintenance and protection will not always be of vital importance. In many cases, the remedies that are available to an Operator outside of cl. 505(b) will be of more value than those provided by it because they will provide faster results. ${ }^{16}$ In addition, the relationship of current and anticipated future revenue to unpaid costs at any point in time, taking into account both the joint lands that are governed by any particular Operating Procedure, as well as all other lands held in common between a particular Operator and JointOperator, will probably have a very direct practical bearing on how the Operator may wish to proceed. In the right circumstances, proper use of the Operator's right to require security or to cash call, or proper management of the proceeds of the sale of production and joint venture billings may provide adequate protection for the Operator at a practical level and reduce the importance of the CAPL lien. Circumstances and business arrangements can render it unlikely that the Joint-Operator will ever owe a significant amount to the Operator for more than a short time. However, in other circumstances, and at certain times, the JointOperator's arrears under a particular Operating Procedure may become significant quickly, and, if the joint lands governed by that same Operating Procedure have any value, then the CAPL lien and the fine points of cl. 505 become important.

\section{REMEDIES AND ENFORCEMENT}

\section{A. The Enforcement Process}

\section{OBSERVATIONS CONCERNING THE PROCESS}

For a step-by-step and in-depth review of the procedural steps involved in enforcing each of the six lien rights laid out in cl. 505(b), we recommend William T. Corbett's article. ${ }^{17} \mathrm{We}$ do not propose to repeat Corbett's analysis or to parrot the language of cl. 505 itself. However, we do wish to make a number of observations.

First, cl. 505(a) contains the statement that "the Operator shall have a lien and charge, which is first and prior to any other lien, charge, mortgage or other security interest ... to secure payment of such Joint-Operator's proportionate share of the costs and expenses incurred by the Operator for the joint account."18 It says that it is "first," but that does not make it first. ${ }^{19}$ Some clients are surprised by this.

The lead-in language to cl. 505(b) states that the list of rights does not limit "the Operator's other rights as contained in this Operating Procedure or otherwise held at law or 
in equity." 20 This begs the question of what other rights the Operator might have at law or in equity.

One important area to consider is the right of set-off. In addition to, and independently of, the CAPL lien contractual remedies, the Operator may have legal or equitable rights of setoff, which may in some circumstances also be of some practical application. In addition, certain statutory rights may result either from registration of the CAPL lien or under statutes that provide the Operator with relationship liens, including rights to force the sale of the Joint-Operator's interest under the Builders' Lien Act, ${ }^{21}$ the Law of Property Act, ${ }^{22}$ the Land Titles Act, ${ }^{23}$ or the Alberta Rules of Court. ${ }^{24}$

However, in our view, for practical purposes, cl. 505(b) includes all of the rights that the holder of a lien and charge on real and personal property would have at law or in equity and expands upon them, and any supplements provided elsewhere do not add anything of significant practical value. ${ }^{25}$ For example, common law or legal liens were passive, in that they only allowed the lien holder to retain the debtor's property until the debt was paid off. They were also dependent upon possession. Equitable liens, charges, and mortgages provided a right of sale. Clause 505(b)(vi) (and various statutory liens) expressly provides a right of sale. $^{26}$

There are some important substantive limits and procedural steps to keep in mind. The CAPL lien applies only to the extent of a Joint-Operator's share of "costs or expenses incurred for the joint account." 27 In addition, they are operative only when a Joint-Operator fails to pay such "costs or expenses incurred for the joint account ... within the time period prescribed by the Accounting Procedure or Clause 502 or 503, as the case may be." 28 Pursuant to cl. 502 (and cl. 103 of the 1996 PASC), the Joint-Operator has 30 days from its

1990 CAPL, supra note 1, cl. 505(b).

BLA, supra note 11.

R.S.A. 2000, c. L-7 [LPA].

LTA, supra note 7.

Alta. Reg. 390/68.

McCachen \& Petrucci, supra note 6, pointed out that the 2007 version expresses the idea that the rights and remedies granted to the Operator "are cumulative, and may be exercised separately or in combination” (at 5). We suggest that any argument that the rights and remedies under cls. 505(b)(1)(i) through (6)(vi) of the 1990 CAPL may not be exercised separately or in combination is very weak. McCachen and Petrucci also observed that "Recognizing the cumulative nature of the remedies, it may be appropriate for an operator to ascend the scale of remedies, by invoking them consecutively, in order to increase pressure on a defaulting non-operator. However, this raises the important point that speed is quite often the more important consideration" (ibid.)

Ibid. at 4.

1990 CAPL, supra note 1, cl. 505(b).

Ibid. On the other hand, the 1996 PASC, supra note 15, cl. 107 (commonly incorporated into the 1990 CAPL by cl. 501), provides that Jointco shall not withhold payment of any portion of a bill presented by Opco due to protest or question related to such a bill unless: (i) the amount involved is significant; and (ii) Opco agrees to the disputed item being withheld. Clause 107 spells out the procedure and details by which each party should conduct itself with respect to the disputed items. The net effect of these provisions seems to be that once Opco presents a bill, Jointco must pay it or be exposed to the remedies set out in cl. 505. However, Jointco is not entirely helpless. In addition to disputing an invoice under cl. 107 of the 1996 PASC, Jointco can point the Operator to cl. 202(b)(ii), which provides for the replacement of Opco if it is in default of "its duties or obligations," and to the case Powermax Energy Inc. v. Argonauts Group Ltd., 2003 ABQB 71, 334 A.R. 1 [Powermax] and suggest to Opco that it would be wise to avoid taking steps under cl. 505(b) until it is certain that it can establish that Jointco may also point out that it will hold Opco liable for any damages that Jointco may suffer should invalid actions by Opco lead to any defaults in Jointco's downstream commitments or obligations, or difficulties with its lenders. 
receipt of an invoice to pay it. In addition, even after those 30 days have passed, none of the remedies listed in cls. 505(b)(iii) through (vi) are available until the Operator has served written notice of default, "specifying the default and requiring it to be remedied." ${ }^{29}$ In our experience, it is common for Operators to forget or ignore these rules.

Clauses 505(b)(i) and (ii) state that the Operator may charge interest and withhold further information and privileges ${ }^{30}$ with respect to “operations conducted hereunder.” Arguably, the withheld information need not be limited to or even relate to the particular operation with respect to which the Joint-Operator may be in arrears. Opco may withhold information even with respect to operations in which the Joint-Operator has not failed to pay costs or expenses. Moreover, Opco may take action under cls. 505(b)(i) and (ii) without giving any notice of default to the Joint-Operator and without waiting. The right to withhold "information and privileges" can provide significant leverage if new and valuable information is coming in fast and furious, but at other times will likely be of little importance. ${ }^{31}$

Clause 505(b)(iii) sets out the CAPL lien right of set-off. ${ }^{32}$ This right extends to sums due to the Joint-Operator under the subject Operating Procedure or "any other agreement between the Operator and such Joint-Operator, whether executed before or after the effective date of the Agreement." ${ }^{\text {"3 }}$ This ability to reach beyond the lands to which the arrears relate and even beyond the subject joint venture agreement into other properties of the Joint-Operator that might be unrelated to the arrears in question is unique among the cl. 505(b) remedies.

At first glance, and especially to a non-litigator, the right laid out in cl. 505(b)(iv) to "maintain an action or actions for such unpaid amounts ... as if the obligation to pay such amounts and the interest thereon were liquidated demands due and payable on the relevant date such amounts were due to be paid, without any right or resort of such Joint-Operator to set-off or counter-claim" does not appear to be particularly significant. ${ }^{34}$ It is obvious that the Operator can sue for the amount owing. However, cl. 505(b)(vi) says more than that. The declaration in cl. 505(b)(iv) that the debt can be treated as a "liquidated demand" provides an important procedural advantage. As the annotation to the 1990 CAPL points out: "[i]n essence, it provides a short cut, in that the operator may be able to avoid having to prove that the work was done and the costs incurred, and could simply assert that the amount is a debt to be collected." ${ }^{35}$ Nonetheless, it is debateable whether this wording will actually have that effect. It seems likely that the Operator would be required to prove the amount of the costs that were incurred, rather than simply pointing to a signed AFE as evidence of a "liquidated demand."

Clause 505(b)(vi) purports to allow the Operator to take possession of (or to use free of charge) all or any part of the Joint-Operator's working interest "in the joint lands," 36 in all

2007 CAPL, supra note 1, cls. 5.05(b), 22.01.

What is meant by the term "privileges"? Our interpretation is that it applies to such matters as the entitlement to inspect records and well sites.

1990 CAPL, supra note 1 , cl. 505(b)(ii).

Ibid., cl. 505(b)(iii).

Ibid.

Ibid., cl. 505(b)(iv).

Ibid.

Ibid. [emphasis added]. 
or any part of the production therefrom and equipment thereon, and all rights, powers, and privileges in connection therewith, and subsequently to sell that interest once having followed the necessary requisite steps. First, note that in contrast to the set-off remedy in cl. 505(b)(iii), this seizure is expressly limited to the assets under the agreement to which the agreement relates (although not to the assets to which the particular arrears relate). In addition, cl. 505(b)(vi) imposes additional notice and time period constraints that apply before the Operator may "sell and dispose of any interest, production, equipment, or production facility of which it has so taken possession." ${ }^{37}$ Whether the Operator is selling oil, gas, a working interest in the lease, or a piece of equipment, it must sell "at public auction or by private tender," and it must serve at least ten days prior written notice to the JointOperator of the time and place of the sale. ${ }^{38}$ These requirements have obvious roots in an attempt to be fair to the defaulting party, but although they may be workable with respect to a sale of a working interest, they can be awkward when applied to a sale of produced oil or gas, especially when deliveries are made via pipeline on a continuous basis.

Moreover, there are practical obstacles that make a sale of the working interest difficult, if not impossible, without also employing the judicial sales provisions of Part 37 of the Alberta Rules of Court. ${ }^{39}$ As Corbett notes, the Novalta ${ }^{40}$ decision confirms that a sale under Part 37 of the Alberta Rules of Court ${ }^{41}$ is the appropriate mechanism for exercising the Operator's rights under cl. 505(b)(vi). ${ }^{42}$ However, considerations of the time and expense involved in the process provided for in Part 37 may influence the Operator's decision to exercise its rights under $\mathrm{cl}$. 505(b)(vi). The Operator would be required to obtain court approval of the auction process, often including a court-approved appraisal of the property, and then obtain court approval at almost every step of such auction process. The proceeds of the auction would likely have to be paid into court and disbursed by court order, and the entire process would be subject to contest by any interested party at every step of the way. Needless to say, this could all take a very long time and involve significant legal and expert costs. It is interesting to note that the Joint-Operators expressly waive any right of relief from forfeiture in the 1990 CAPL. ${ }^{43}$

\section{Priority Issues}

\section{A. The CurRent Relevance of Common LAW AND Equitable PRIORITY RULES TO OPERATORS’ LIENS}

In Alberta, a network of legislation addresses the registration, priority, and enforcement of security interests. The principal players are the MMA, the LPA, the LTA, and the Personal Property Security Act. ${ }^{44}$ Together, these statues codify a very comprehensive set of security interest priority rules (although one or more other statutes may also apply especially in

Ibid., cl. 505(b)(vi).

Ibid. Revisions in the 2007 CAPL attempt to address this issue by purporting to allow an automatic assignment at the well head, upon five business days written notice.

Revisions in the 2007 CAPL expressly contemplate a court-ordered sale.

Novalta Resources Ltd. v. Ortynsky Exploration Ltd. (1994), 151 A.R. 161 at para. 152 (Q.B.) [Novalta].

Supra note 24.

Corbett, supra note 12 at 16.

1990 CAPL, supra note 1, cl. 2807.

R.S.A. 2000, c. P-7 [PPSA]. 
relation to enforcement, according to the facts in a particular situation - including the $B L A$, the Bank Act, ${ }^{45}$ the Bankruptcy and Insolvency Act, ${ }^{46}$ the Companies' Creditors Arrangement $A c t,{ }^{47}$ the Judicature Act, ${ }^{48}$ and the Statute of Frauds, $1677^{49}$ ). The MMA, LTA, and PPSA also include statutory exceptions to the priority rules set out within them. Certain exceptions might be interpreted as open doors to the common law for the resolution of some priority questions. For example, the Operator may argue, "yes, so far as the 1990 CAPL and the statute goes, I lose; but I have rights that exist beyond contract — such as my right to a possessory lien in the well site equipment and the severed production — and these rights are beyond the reach of that legislation, or are included within the statutory exceptions." However, in our view, for the purposes of the Operator's Lien, and for all practical purposes, any such doors appear to be closed.

Therefore, in this article, we do not consider it necessary to conduct a full examination of how the Operator's lien should be categorized under common law and equitable principles, or how the common law and equitable rules would apply in priority contests in the variety of possible factual situations that might arise. However, we will offer a summary of a couple of potentially significant rules. First, if the equitable rules do apply in a particular situation, it will be important to know when the Operator's rights first arose in that situation. It will be valuable to an Operator to have a lien that arises before the competing interest arises. ${ }^{50}$ To the extent that the Operator's interest is competing with another equitable interest, the first to arise will likely prevail. Second, if the competing interest might be characterized as a legal one, it will be important for the Operator to have given notice of its Operator's lien to the competing party before that other interest arises. If the Operator's lien is or includes an equitable interest in land, it might defeat a legal interest that arises subsequent to it and with notice of it. It may be sufficient that notice be constructive as opposed to actual. Therefore, it may be prudent to take advantage of any form of registration that may help to support an argument that a third party had constructive notice of the existence of the CAPL lien.

For a detailed analysis of the characterization of the various competing interests and the workings of the rules, we recommend Karen Pettifer's article, ${ }^{51}$ Corbett's article, ${ }^{52}$ and the voluminous case law and textbooks on equity on which those able writers based their summaries.

We will now turn to consideration of the referenced statutes and the closed doors.

S.C. 1991 , c. 46 .

R.S.C. 1985 , с. B-3 [BIA].

R.S.C. 1985, c. C-36 [CCAA].

R.S.A. 2000, c. J-2.

(U.K.), 29 Car. II, c. 3.

Corbett, supra note 12 at 11, discusses the question of when an Operator's lien arises - i.e., whether at execution of agreement or upon failure to pay.

Pettifer, supra note 12.

Corbett, supra note 12 . 


\section{B. The Statutory Priority Scheme}

\section{The Mines AND Minerals ACT AND THE LAW OF PROPERTY ACT "LAND CHARgE"}

Section 94(1)(b) of the MMA defines an "operator's lien” and s. 94(1)(e) defines a "security interest." An Operator's lien is not a security interest and so is not registrable under the $M M A .^{53}$

Section 94(1)(b) of the MMA reads as follows:

(b) “operator's lien” means an interest in or charge on collateral if

(i) the interest or charge arises under a contract to which an owner of the collateral is a party,

(ii) the contract provides for the conduct by a person, called in this clause the "operator", other than that owner, of exploration, mining, drilling, development, production, processing or abandonment operations in respect of the mineral to which rights are granted by the agreement concerned,

(iii) the contract requires that owner to make payments to the operator to cover all or part of the advances made by the operator in respect of the cost of those operations, and

(iv) the interest or charge secures the payments referred to in subclause (iii). ${ }^{54}$

Section 95(4) of the MMA reads in part as follows:

A security interest in respect of which a security notice is registered has priority

(a) over any other security interest acquired before the registration of that security notice unless the security notice in respect of that other security interest is registered before the registration of the first-mentioned security notice,

(c) over any builder's lien acquired before the registration of that security notice unless that builder's lien is registered before the registration of that security notice, and

(d) over any interest, right or charge acquired after the registration of that security notice. ${ }^{55}$

It is clear that a CAPL lien is an Operator's lien, and that it therefore cannot be registered under this section. Although there is some room to argue otherwise, it appears that relationship liens will also fall within the definition of the Operator's lien or will otherwise fall short of the definition of a "security interest" in the MMA. Thus an Operator's lien cannot be registered under Part 6 of the $M M A$ regardless of which way one approaches it, and cannot 
benefit from the priority granted by it to a security interest. ${ }^{56}$ However, what is not so clear is the extent to which an Operator's lien is subject to the priority that Part 6 of the MMA gives to registered "security interests." 57

What was the legislature's reason for taking this approach? Also, was that policy intentionally reversed or affected by s. 64 of the $L P A{ }^{58}$ We have reviewed the Hansard from the time that Part 6 of the MMA (which encompasses ss. 94 and 95) was proposed, ${ }^{59}$ and although no in-depth explanation for the exclusion of an Operator's lien was given, it is apparent that the primary purpose of Part 6 was to allow financial institutions (with specific preference being given to banks ${ }^{60}$ ) to register security against Crown-owned mines and minerals. ${ }^{61}$ Whatever the legislature intended, the effect of s. 95 is to elevate secured lenders over other types of secured creditors. One can question whether the legislature's intention in expressly excluding the Operator's lien from the protections afforded by s. 95 was to subordinate them to secured lenders, to recognize that Operators' liens were already registrable under that Act as builders' liens, or to leave Operators' liens to be addressed by s. 64 of the $L P A .^{62}$ However, it is interesting to take note of the contrasting approach taken in the Canada Petroleum Resources $A c t^{63}$ and comparable legislation resulting from Newfoundland and Nova Scotia Accords. ${ }^{64}$ As the annotations to the 1990 CAPL point out, they "expressly provide the operator with certain advantages in enforcement as regards frontier properties, in recognition of the fact that lenders should realize that an operating agreement will probably exist under which the operator would almost certainly have a lien.”65

Are Operators' liens to be considered builders' liens for purposes of the $M M A$, and so addressed by ss. 95(4)(c) and 95(5)? Returning to our distinction between the CAPL lien and the relationship liens, we suggest elsewhere in this article that it is arguable that, in some circumstances, an Operator has a "builders' lien," which we would categorize as a "relationship lien" and which exists outside of the 1990 CAPL. The CAPL lien is contractual and therefore not a builders' lien as defined in the $B L A .{ }^{66}$ The builders' lien arises from the Operator's actions, as opposed to the wording in cls. 505(a) or (b) of the 1990 CAPL. To the extent that an Operator has a builders' lien, it can be registered under the $M M A$ and where

56 Ibid., ss. 94-95

57 Ibid. We note that this exclusion may not apply in circumstances where it is the Joint-Operator, rather than the Operator who is, exercising lien rights under the 1990 CAPL, supra note 1, cl. 505(b). Of particular interest in this regard is that cl. 606 grants the Joint-Operator a lien where the Operator fails to remit proceeds.

$58 \quad$ Supra note 22, s. 64.

$59 \quad$ See Alberta, Legislative Assembly, Alberta Hansard, 1981-1982, May 22- March 1 (2 November 1981) at 1397 (Mr. Leitch); Alberta, Legislative Assembly, Alberta Hansard, 1981-1982, May 22-March 1 (1 June 1981) at 1047 (Mr. Leitch); Alberta, Legislative Assembly, Alberta Hansard, 1980-1981, May 1March 30 (20 May 1980) at 1065 (Mr. Leitch).

$60 \quad$ MMA, supra note 7, s. 95(5).

61 Sections 95(2) and (6) of the MMA provide an interesting exception to the priority set out in s. 95(4) security interests created before 16 December 1981 that were not security under the Bank Act are not registrable, but are exempt from the priority scheme set out in the $M M A$. Presumably, provided the interest arose after 6 June 1974, its priority is now determined by s. 64 of the LPA. If an Operator's lien arose before 16 December 1981, or an Operator found itself in a priority contest with the holder of such an exempt security interest, query what priority rules would apply?

LPA, supra note 22, s. 64.

R.S.C. 1985 (2nd Supp.), c. 36 [CPRA].

Canada-Newfoundland and Labrador Atlantic Accord Implementation Newfoundland and Labrador Act, R.S.N.L. 1990, c. C-2, s. 108(5); Canada-Nova Scotia Offshore Petroleum Resources Accord Implementation (Nova Scotia) Act, S.N.S. 1987, c. 3, s. 115(5).

$65 \quad 1990$ CAPL, supra note 1, cl. 505.

$66 \quad$ Supra note 11. 
unregistered will lose to a security interest that is registered, even if the lien arose before the registration of the applicable security notice. ${ }^{67}$

Nevertheless, that does not address the CAPL lien. It seems unlikely that the legislature intended that an Operator's rights under the MMA should be addressed only on the basis of the builders' lien that the Operator may have independently of contract. The builders' lien theory does not seem to provide an answer to our question about Operators' liens and s. 95 of the $M M A$ that is either complete or satisfactory.

Section 95(4)(d) applies to CAPL liens because a CAPL lien is an "interest, right or charge.”68 But s. 95(4)(d) only addresses priority that concerns an interest, right, or charge that is acquired after the registration of a security notice - not those that were acquired before. $^{69}$

This all begs the question: what law governs the priority of an Operator's lien relative to a security interest if the Operator's lien was acquired before the registration of that security interest?

There appear to be two possible answers:

1. Section 64 of the $L P A$, discussed below; or

2. Common law principles, including the rule that any party who acquires a legal interest in land holds that interest subject to a prior equitable estate in that same land of which that party had actual or constructive notice. ${ }^{70}$

Section 64 of the LPA reads in part as follows:

In this section,

(b) "charge on land" means an interest, whether arising immediately or in the future, in real property given by a corporation, that secures payment or performance of an obligation;

(c) “real property" means land, an interest in land...;

(d) “registered" means registered by means of a financing statement in the Personal Property Registry in accordance with the Personal Property Security Act and the regulations made under that Act.

Registration is effected under the BLA, ibid., s. 36, the Crown Minerals Registration Regulation, Alta. Reg. 264/97, ss. 1-2, and the Mines and Minerals Administration Regulation, Alta. Reg. 262/97, Sch. Priority under the MMA is determined by ss. 95(4)(c), 95(5).

$68 \quad$ MMA, supra note 7, s. 95(4)(d).

69 Ibid.

$70 \quad$ See Pettifer, supra note 12 at 103. 
(2) Subject to subsections (8) and (12), except in the case of fraud, priority among successive charges on land affecting the same interest shall be determined as follows:

(a) priority between registered charges on land shall be determined by the order of registration without regard to the order of creation of the charges or execution of the agreements providing for the charges;

(b) a registered charge on land has priority over an unregistered charge on land;

(c) priority between unregistered charges on land shall be determined by the order of execution of the agreements providing for the charges.

(8) This section is subject in all respects to the Land Titles Act and the Mines and Minerals Act, and the priority of any interest registered or filed under either Act shall be determined pursuant to that Act. ${ }^{71}$

Clause 505(a) of the 1990 CAPL states that the Operator has a "lien and charge."72 There seems to be little doubt that the CAPL lien includes a "charge on land" as defined in s. 64 of the $L P A$ and, to that extent, the CAPL lien is subject to s. 64 of the $L P A .^{73}$ Although there is no reference to s. 64 of the $L P A$ in either the $L T A$ or the MMA, s. 64 of the $L P A$ appears to supplement (but remain subject to) both the LTA and the MMA. It creates a bridge (accepted by s. 42(2) of the PPSA) between the LPA and the PPSA; the two work together to provide that priorities with respect to a charge on land are determined according to registrations effected under the $P P S A$, subject to any competing or overriding provision in either the LTA or the MMA. Section 64 of the LPA was enacted in 1992 (a long time ago for lawyers admitted to the bar since Jimmy Carter was President), long after what is now Part 6 of the MMA. The legislature that passed s. 64 would have been aware of the existence of CAPL liens and their treatment in the MMA, and so it seems reasonable to suggest that it intended to encompass them within the reach of s. 64. This means that the CAPL lien, to the extent that it includes a charge on land (that is, an interest in real property given by $a$ corporation), is registrable at the Personal Property Registry under the LPA in relation to Crown land. ${ }^{74}$ More importantly:

- if it is not registered under the $L P A$, it is expressly subordinated by the $L P A$ to charges on that same Crown land that are registered under the $L P A ;^{.75}$ and

- $\quad$ if it is not registered under the $L P A$, it still might have priority (with respect to land as opposed to personal property) over bank or other security that is acquired after it is created, even if that other security is registered under the $M M A$ but is not registered at the Personal Property Registry against the subject Crown land as a charge on land,

LPA, supra note 22, s. 64 [emphasis added]. Section 64(2)(c) of the $L P A$ appears to be a codification of the equitable principle set out in Rice v. Rice (1853), 2 Drew. 73, 61 E.R. 646 at 648 (Ch.), that when the equities are otherwise equal, the first in time prevails.

Supra note 1, cl. 505(a).

Supra note 22, s. 64(1)(b).

If it is given by an individual, it seems that it is not caught by s. 64 of the $L P A$ or the MMA.

LPA, supra note 22, s. 64 . 
because (a) the MMA does not give priority over an Operator's lien acquired before the registration of a security notice $;^{76}$ and (b) the $L P A$ rules may therefore govern that particular competition. ${ }^{77}$

With reference to Crown lands and the $M M A$, would a failure to register an Operator's lien under the $L P A$ be fatal as against a Bank Act security interest registered under the $M M A ?^{78}$ Can s. 64(8) of the LPA be read as showing an intention that a contract involving those facts should be determined by common law principles? ${ }^{79}$

The non-registration of the Operator's lien would probably be irrelevant in many fact situations because the MMA registration will settle the question of their relative priority. ${ }^{80}$ Nonetheless, in other scenarios the non-registration of the Operator's lien under the LPA would cause the loss of an opportunity. ${ }^{81}$ If the Operator's lien could have been registered under the LPA before the Bank Act security is registered under the LPA, then the Operator could have defeated the Bank Act security on the basis of the LPA by registering under the LPA before the bank did, but instead will lose to it because it did not. ${ }^{82}$ If the Bank Act security was acquired after the Operator's lien was acquired, then their relative priority is not addressed by s. 95(4)(d) of the MMA, and the Operator's lien will prevail under s. 64 (2)(c) of the $L P A$, unless and until the MMA security is registered under the LPA before the Operator's lien is. ${ }^{83}$

We are suggesting that although a priority contest between an unregistered charge on land (which is not a security interest under the $M M A$, and so is not registrable under the $M M A$ ) and a registered $M M A$ security interest is not governed by the $M M A$, it is governed in all scenarios (except one involving a charge on land granted by an entity that is not a corporation) by the $L P A{ }^{84}$ Section 64 of the $L P A$ will deal with these competing interests on the following basis: (a) the first to be registered under the LPA will prevail; (b) the first to have been executed will prevail if neither is so registered; and (c) the MMA registration is irrelevant to this particular contest. Section 64(8) of the LPA means only that the LPA will not take away a right that is granted by the $M M A$, and, in this scenario, the bank has no $M M A$ priority over the Operator's lien. ${ }^{85}$ It also follows from this interpretation that if an interest that is registrable and registered under the $M M A$ is also registered under the $L P A$, it may gain a priority that is not given to it by the $M M A$ registration, such as, priority over interests that are not registrable under the $M M A$, including an Operator's lien, that was acquired before the $M M A$ security interest was acquired. ${ }^{86}$ If one turns to the same contest but with reference to personal property located on Crown lands, then the contest is determined by the comprehensive scheme of the PPSA, rather than the $L P A$ or the $M M A .{ }^{87}$ It is curious that a

MMA, supra note 7, s. 94(1)(e).

LPA, supra note 22, s. 64.

MMA, supra note 7, s. 94(2)(b).

LPA, supra note 22, s. 64(8).

MMA, supra note 7, s. 95(4).

LPA, supra note 22, s. 64.

Ibid.; Bank Act, supra note 45.

MMA, supra note 7, s. 95(4)(d); LPA, supra note 22, s. 64(2)(c); Bank Act, ibid.

LPA, ibid., s. 64.

Ibid., s. 64(8).

See ibid., s. 64.

PPSA, supra note 44; LPA, ibid.; MMA, supra note 7. 
statutory provision that has as significant an effect as s. 64 of the LPA does has received so little fanfare and attention. However, to date we have not encountered credible arguments to counter the above interpretation.

In conclusion, all priority questions involving Operators' liens and relating to Crown lands appear to be answered by s. 95(4)(d) of the MMA or s. 64 of the LPA. It is difficult to see a realistic scenario in which we must refer to common law and equitable principles.

\section{THE LAND TITLES ACT}

As we turn to freehold land, we turn from Part 6 of the $M M A$ to the priority scheme of the LTA. Under the LTA: ${ }^{88}$

1. An Operator's Lien that is not registered by caveat will not have any status under the LTA and will be defeated by any competing interest that is registered under the LTA; and

2. Priority as between competing interests that are both registered under the LTA will be determined by the order in which they were registered.

Several useful questions can be posed as one seeks to apply the LTA to the CAPL lien:

1. Can the CAPL lien or any of the relationship liens be validly registered under the LTA?

2. If it is not registered there, what is the effect of non-registration on either (i) enforcement against the Joint-Operator in the absence of any priority dispute with another secured party, or (ii) a priority dispute with another secured party?

3. Does the LTA provide a complete answer to these questions, or does it leave room for common law or equitable principles to play a role?

Whereas the question under the MMA relates to the treatment of Operators' liens under s. 94, the question under the LTA is only whether the Operator's lien includes an interest in land.

The CAPL lien is registrable under s. 130 of the LTA to the extent that it relates to freehold land (that is, land that is patented and governed by the LTA, and is not owned by the Crown) and includes an interest in land. ${ }^{89}$ (With the exception of a builders' lien on freehold land, any argument that the relationship lien includes an enforceable interest in land, and so can be caveated under the LTA, seems to run into serious difficulty with the Statute of Frauds, because relationship liens are not created by a signed document.) Pettifer, writing

LTA, ibid., s. 130. Section 202 of the $L T A$ makes it clear that no caveat or encumbrance can be registered under the LTA in respect of Crown owned land, even if a patent has been issued so as to bring it under the LTA. 
with reference to the 1981 CAPL Operating Procedure,${ }^{90}$ questioned whether the Operator's lien created by the 1981 CAPL is a legal lien (that is, merely possessory) or an equitable lien or charge, noting that the former would not be registrable under the LTA, while the latter would be. ${ }^{91}$ Corbett referred to that question and concluded that the CAPL lien under the 1990 CAPL "appears to be an equitable lien or charge,"92 and that it would be registrable under the $L T A .{ }^{93}$ We concur.

As to question (2)(i), above, s. 53 of the LTA states in part that no instrument is "effectual to pass any estate or interest" in freehold land unless the instrument is registered under the LTA. ${ }^{94}$ Nevertheless, it seems likely that a court would allow an Operator to enforce its lien (charge) on freehold land so long as no party who has a registered interest under the LTA has a valid objection, although the court might require registration before allowing enforcement. Perhaps an issue exists as to whether a bankruptcy court, or a CCAA order, should treat the unregistered Operator as an unsecured creditor insofar as freehold land is concerned. One can see that in an enforcement scenario it would be preferable for an Operator to have protected its lien by caveat, so as to render s. 53 a non-issue. ${ }^{95}$

Turning to question (2)(ii), above, the priority scheme of the LTA is comprehensive. Corbett said that the $L T A$ provides an "all inclusive registration and priority system" whereas the $M M A$ does not. ${ }^{96}$ The $L T A$ scheme, its recognition of unregistered or equitable interests, and the exceptions to the indefeasibility that are provided by the LTA, are the subject of many cases, papers, and textbooks. It is not necessary to get into the details here. Suffice it to say for now that ss. 14, 53, 56, 62, and 203 of the LTA seem to leave little room to argue that an unregistered Operator's lien (CAPL or relationship) has any status whatsoever against any party who has registered its interest under the $L T A$, regardless of matters such as relative timing and prior notice. Section 107 of the LTA does recognize a concept of postponement, but only if the prescribed form is filed. The LTA certainly does not contain an open door to unregistered subordination agreements in the way that s. 40 of the PPSA (which is discussed below in Part V.D of this article) does. Further, it is very clear that insofar as registered interests are concerned, priorities are determined by the order of registration. ${ }^{97}$

As to a competition between two unregistered interests involving an Operator's lien and concerning freehold land, it would appear that s. 64 of the LPA provides a very clear answer subject to the questions raised above. ${ }^{98}$

1981 CAPL Operating Procedure (Calgary: Canadian Association of Petroleum Landmen, 1981) [1981 CAPL].

Pettifer, supra note 12 at 98-103.

Corbett, supra note 12 at 8.

Ibid. at 11; see also 274489 Alberta Ltd. v. Dhillon (1982), 41 A.R. 574 (Q.B.).

LTA, supra note 7, s. 53.

Ibid.

Corbett, supra note 12 at 26.

We query whether the recent Alberta Court of Appeal decision, 1244034 Alberta Ltd. v. Walton International Group Inc., 2007 ABCA 372, 422 A.R. 189, has an impact on priority.

In Royal Bank v. Head West Energy Inc., 2007 ABQB 188, 430 A.R. 15, Bielby J. said at para. 39: “The LPA determines priority among charges on land registered pursuant to it up until such time those charges are also registered under the LTA. The latter then governs priorities from that point onward." 
The LTA does not contain a provision like s. 95 of the $M M A$, which requires special analysis of how an Operator's lien fits within its rules. ${ }^{99}$ It does not contain a provision to correspond to s. 20 of the PPSA, which expressly puts the holder of an unregistered security interest in the position of an unsecured creditor (as concerns personal property) following the bankruptcy of the debtor (unless s. 53 has that effect). ${ }^{100}$ It does not contain anything like s. 32 of the PPSA which, as discussed below, may open a door beyond the PPSA priority scheme for relationship liens, and provides that they may have priority (as to personal property) over an interest registered or otherwise perfected under the PPSA. ${ }^{101}$

It appears that the common law priority rules do not have any relevance to Operators' liens to the extent that they apply to Alberta freehold land. The exceptions to indefeasibility are set out in s. 61(1) of the LTA and they do not include Operators' liens. ${ }^{102}$ As Pettifer said, "[c]ertain statutory exceptions are not enumerated in this section, however, it is questionable whether possessory rights created by contract can constitute a further exception to what is considered by most to be a complete statutory registration system and priority scheme.”103 In any case in which neither competing interest is registered under the LTA, s. 64 of the LPA probably provides a complete answer. ${ }^{104}$

\section{THE PERSONAL PROPERTY SECURITY ACT}

Here again, it is important to approach our analysis from the starting point that the Operator's lien applies to both personal and real property. The PPSA applies only to the personal property components of the joint property (except to the extent that it provides the mechanism for the registration of the LPA charge on land). ${ }^{105}$ The underlying working interest, which is a real property interest, provides the foundation for value, but the personal property components can be very valuable, and so PPSA registration should not be ignored. The personal property includes severed production and the proceeds of the sale of such production. In some cases a creditor may be content to limit its realization to the proceeds of production, and one certainly would not want to be perfected in respect of the real property but exposed in respect of the proceeds of production.

The PPSA arguably provides a complete priority scheme insofar as the Operator's lien encumbers personal property. The residual PPSA scheme of priority is laid out in s. 35, which applies where the PPSA "provides no other method for determining priority between security interests." ${ }^{״ 106}$ However, depending on the circumstances, it may not be as simple as fitting the Operator's lien in among other security interests under s. 35 of the PPSA.

Generally speaking, priority between perfected security interests is determined by the order of occurrence of the registration of a financing statement, possession of the collateral under s. 24 (in both cases without regard to the order of attachment), or perfection under one 
of ss. $5,7,26,29$, or 75, whichever is earlier. A perfected security interest has priority over an unperfected security interest. Also, "priority between unperfected security interests is determined by the order of attachment of the security interests." 107

Pursuant to 35(1)(a), then, and with reference to personal property only, we seem to have a complete priority scheme. ${ }^{108}$ The Operator who registers a financing statement under the PPSA obtains priority over any subsequently filed financing statement, and over any unperfected security interest, at least to the extent of that personal property in which 1990 $C A P L$ gives the Operator a security interest and to the extent that the Operator's financing statement is properly worded under PPSA rules relating to the description of collateral. We note that the 1990 CAPL has some deficiencies concerning effectively encumbering some types of personal property included within the Joint-Operator's interests. For instance, although the term "equipping" is defined in the 1990 CAPL, the term "equipment" is not. ${ }^{109}$ Section 10(3) of the PPSA states that a security interest will not be enforceable against third parties where it describes "equipment" without further description of the "kind of collateral" involved. ${ }^{110}$

However, the Operator who does not register will lose in a priority contest with any security interest that is registered, and will compete (as to personal property) with other unregistered interests on the basis of the PPSA concept of "attachment," which is addressed in detail in ss. $12,12.1$, and 13 of the PPSA, and which, for purposes of the CAPL lien, probably occurs when the $1990 \mathrm{CAPL}$ is signed. ${ }^{111}$

The PPSA contains another noteworthy provision. Section 20(a)(i) states that: "A security interest (a) in collateral is not effective against (i) a trustee in bankruptcy if the security interest is unperfected at the date of bankruptcy."112 Therefore, the Operator who does not register under the PPSA has at least two worries relative to personal property interests: (i) it will lose any priority contest with any holder of a PPSA security interest who has validly registered; and (ii) in the event of a bankruptcy, it might be treated as an unsecured creditor.

It is also noteworthy that registration is not the only means of obtaining perfection under the PPSA. The PPSA gives priority to the first to take one of the three measures specified for perfection in s. $35 .{ }^{113}$ Once again, these are: (i) effective, valid registration of a financing statement; (ii) taking possession in the manner contemplated by s. 24; or (iii) "perfection under section 5, 7, 26, 29 or 75."114 Only the first two measures are relevant considerations with respect to Operators’ liens.

Corbett suggested that, in a priority dispute between the holder of a registered general security agreement and the holder of an unregistered Operator's lien, the Operator might

Ibid., s. 35(1)(c).

Ibid., s. 35(1)(a).

1990 CAPL, supra note 1, cl. 101(l).

PPSA, supra note 44, s. 10(3). Section 10 was revised in 2006 but with an apparent error - s. 10(3) was not amended so as to refer to s. 10(1)(d) as opposed to 10(1)(b): see Richard H. McLaren, The 2008 Annotated Alberta Personal Property Security Act (Toronto: Thomson Carswell, 2008) at 108.

See PPSA, ibid., ss. 10(d), 12.

Ibid., s. 20(a)(i).

Ibid., s. 35.

Ibid., s. 35(1)(a). 
prevail if it was in possession of the personal property before the time at which the holder of the general security agreement registered it under the PPSA. Corbett concluded that "[i]n most circumstances, I believe the Operator will be found to be in possession of the property involved in the dispute."115 He also suggested that an Operator's possession might constitute perfection by possession, such that the unregistered Operator's lien might escape the consequences of s. 20(a)(i) of the PPSA. ${ }^{116}$

It is not clear that the possession of an Operator's share of the well site equipment and production constitutes the type of possession contemplated by s. 24 of the PPSA. Section 24(1) itself states that:

Subject to section 19, possession of the collateral by the secured party, or on the secured party's behalf by another person, perfects a security interest in

(a) goods

(f) money,

but only while it is actually held as collateral and not while it is held as a result of a seizure or repossession. ${ }^{117}$

Is the property of the Joint-Operator held by the Operator as collateral in order to secure the Joint-Operator's obligations, or is it in the Operator's possession merely out of practical necessity? No mention of the Operator's possession appears in cl. $505{ }^{118}$ There is no language in cl. 505 of the 1990 CAPL that states that the Operator is holding the JointOperator's oil, surface rights, or money (all of which are probably encompassed within s. 24 of the PPSA) as collateral. Further, it is clear from the restricted list of the types of personal property that can be perfected by possession under s. 24 that neither a security interest in intangibles (such as contracts) nor a security interest in a non-negotiable document can be perfected by possession, and, obviously, even if the Operator does have PPSA possession, the PPSA will not provide for the perfection of the Operator's security interest in land by possession. ${ }^{119}$ We also refer to Ronald Cuming and Roderick Wood in Alberta Personal Property Security Act Handbook, where they state:

The Act does not define the term "possession”. Moreover, the term was not used with precision under common law. The meaning of the term varied according to the circumstance.... The "possession" contemplated by section 24 must be sufficient to indicate to third parties that the debtor has given a security interest in the collateral to the secured party. Under section 24(2), possession will be insufficient for the purposes of section 24(1) if the collateral is in the apparent possession or control of the debtor. ${ }^{120}$

Corbett, supra note 12 at 21.

Ibid.

PPSA, supra note 44, s. 24(1) [emphasis added].

1990 CAPL, supra note 1 , cl. 505.

PPSA, supra note 44, s. 24.

Ronald C.C. Cuming \& Roderick J. Wood, Alberta Personal Property Security Act Handbook, 4th ed. (Scarborough: Carswell, 1998) at 221-22. 
Any comfort that an Operator might take from the reference to perfection by possession under s. 35 of the PPSA could be very limited.

Based on the foregoing, the PPSA does not appear to leave any room for arguments based on the common law and equitable priority rules, or provide any protection for the unregistered CAPL lien, and so the unregistered Operator's lien cannot look to those rules for assistance in a priority contest. But can it find assistance in s. 32 of the PPSA?

a. $\quad$ Section 32 of the Personal Property Security Act and Operators' Liens: The Caribou Decision

Section 32 of the PPSA reads as follows:

Where a person in the ordinary course of business furnishes materials or services with respect to goods that are subject to a security interest, any lien that the person has with respect to the materials or services has priority over a perfected or unperfected security interest in the goods unless the lien is given by an Act that provides that the lien does not have the priority. ${ }^{121}$

If s. 32 applies to Operators' liens, then the Operator's lien will have priority over perfected or unperfected security interests as defined in PPSA - at least with respect to personal property, if not real property. ${ }^{122}$ On its face, s. 32 does not address the relative priority of two competing s. 32 liens. However, in that instance the residual priority rules under s. 35 (that is, by order of attachment) or other governing statute as referenced in s. 32 would govern. All very interesting, and the source of a great deal of optimistic speculation for writers considering the fate of the unregistered Operator's lien under the PPSA - but at this point in time, the law in Alberta is that s. 32 does not apply to CAPL liens.

We represented the losing side in Caribou $^{123}$ in which s. 32 of the PPSA became an important topic. Bearspaw Petroleum Ltd. was the Operator and the Processor under a number of agreements with Caribou Resources Corp. Caribou had obtained creditor protection under the CCAA. Bearspaw sought a court declaration that its Operator's and Processors' liens had priority over Caribou's secured lender's security. The lender had registered its debenture security against both personal property and real property at the Personal Property Registry and under the $M M A$, respectively. Bearspaw had not registered its Operators' liens.

In her judgment, Horner J. stated that two issues were put before the Court: (1) whether s. 32 of the PPSA applied to Bearspaw's Operators' and Processor's liens such that Bearspaw's unperfected interests would have priority over the perfected security interests of the lender; and (2) whether the wording of the permitted encumbrance clauses in the subject loan agreements, combined with equity, was sufficient to contractually subordinate the secured lender's security to the Bearspaw liens. ${ }^{124}$ Because of the potential importance of

$121 \quad$ PPSA, supra note 44, s. 32.

Ibid.

Re Caribou Resources Corp. (18 December 2007), Calgary 0701-01113 (Alta. Q.B.) [Caribou]. Ibid. at 49. 
s. 32 to Operators' liens, we will now examine the decision on that point. (The decision on subordination takes us beyond the PPSA and as such we will address it later, in Part V.D.)

On a plain reading of s. 32, an Operator's lien would appear to fall within the purview of s. 32. However, relying on the earlier decision in Kalta, ${ }^{125}$ which in turn had relied on s. 32 commentary by Cuming and Wood, Horner J. found that s. 32 did not apply to Bearspaw's liens. $^{126}$

Cuming and Wood have stated that a four-part test must be met in order for s. 32 to apply:

There are four conditions that must be met in order to fall within the language of section 32. First, the nonconsensual security interest must take the form of a lien. Other types of non-consensual security interests (such as a deemed statutory trust) would not qualify. Second, the lien must be on goods. This excludes liens on shares, on an award of damages or proceeds of an insurance policy. Third, the lien claimant must supply materials or services in respect of the goods. Section 32 does not draw a distinction between work that enhances the value of the goods and work which preserves its value.... Fourth, the materials must be furnished in the ordinary course of business of the lien claimant. ${ }^{127}$

The term "non-consensual," which appears in the first part of the Cuming and Wood four-part test does not appear in s. 32. Cuming and Wood offered no direct explanation of its meaning, and only an indirect explanation of their use of the term in their first test. ${ }^{128}$ However, based on Professor Wood's discussion of s. 32 in the Alberta Law Reform Institute's Omission Report on Liens, it appears that a non-consensual lien is one that arises either by statute, rule of common law, or equity — not by contract. ${ }^{129}$ Thus, the Cuming and Wood position is that a contractual lien (which, by implication, is a consensual lien) is not within the purview of s. 32. Its relative priority is governed by the priority principles set out elsewhere in the PPSA.

It appears that the basis for Cuming and Wood's view that the term non-consensual should be implied into s. 32 is that s. 32 should be read in conjunction with s. 4, which provides for a qualified exclusion of liens arising by rule of law or statute from the purview of the PPSA. ${ }^{130}$ Section 4 excludes a list of interests from the operation of the PPSA. Cuming and Wood appear to have noted that all of the exempt interests listed in s. 4 could be called "nonconsensual," and it appears that they then read the special status given to liens in s. 32 as being limited to non-consensual liens. ${ }^{131}$

Direct Energy Marketing Ltd. v. Kalta Energy Corp., [2002] A.J. No. 463 (QL) [Kalta].

Caribou, supra note 123 at $49-50$.

Cuming \& Wood, supra note 120 at 302 [footnotes omitted]. Master Breitkreuz adopted the Cuming and Wood criteria, "including the requirement that the interest be a non-consensual security interest": see Kalta, supra note 125 (citing Craddock Trucking Ltd. v. Leclair (1995), 28 Alta. L.R. (3d) 145 at 148-49).

128 Cuming \& Wood, ibid.

129 Alberta Law Reform Institute, Report on Liens, Report for Discussion No. 13 (Edmonton: Alberta Law Reform Institute, 1992) at 40.

$130 \quad$ Cuming \& Wood, supra note 120 at 301.

131 Ibid. 
Let us examine that position. First, the exclusion in s. 4 uses the words "a lien, charge, or other interest given by an Act or rule of law in force in Alberta." 132 Those words are not used in s. 32. Cuming and Wood interpreted the PPSA as if those words are in both ss. 4 and 32. Next, consider that the courts have held that a general lien can arise either by express contract or by trade custom. ${ }^{133}$ It can be argued that a general lien remains a lien given by rule of law irrespective of the fact that it is expressly provided for in a written contract. It appears that in order for the Cuming and Wood position to hold, an additional qualification must be read into s. 32 to the effect that even where the lien is given by rule of law, such that it is within the protection of s. 32, it will lose that protection if it is evidenced by a written contract.

Other writers commenting on s. 32 adopt the Cuming and Wood four-part test and suggest that the purpose of s. 32 is to protect small creditors, such as suppliers, who have a lien and for whom a written contract and registration is not practical. ${ }^{134}$ This interpretation seems to read into s. 32 considerations of the creditor's size and sophistication. This appears to stray far from the plain meaning of the words employed in s. 32.

This leads us to the main point to consider. The Cuming and Wood interpretation is not a plain meaning interpretation. The words in s. 32 do not contain an express exclusion of consensual liens.

Richard McLaren appears, at least in part, to support a plain meaning interpretation, although he too uses the term non-consensual. ${ }^{135}$ Policy considerations seem to us to favour a plain meaning interpretation, because such an interpretation responds to certain practical realities in the oil and gas industry. Consider the practical implications if all Operators (and all Processors) were to register all of their liens and change statements to reflect all assignments to new Joint-Operators - the registry would be inundated. In addition, because Joint-Operators will generally obtain secured financing from a bank prior to signing the Operating Procedure, Operators will rarely have an opportunity to register before the bank does, and so for all practical purposes they will always rank behind the bank in priority, even if they do register (at least in the first instance of ownership).

The commercial reality is that Operators do not register all of their liens because it is impractical to do so, and we suspect that the industry as a whole may not want them to register all of their liens. At the same time, the industry and its lenders and investors are all fully aware of Operators' liens and of the essential role they play in the mechanisms by which money is advanced so as to develop property and to increase value for the benefit of all stakeholders. The purpose of s. 32 seems to be to give protection to certain parties who have a particular kind of relationship with a debtor, because without that protection, those parties, by virtue of the nature of their relationship, will almost always be subject to the prior (Toronto: Carswell, 1985) at 579-80; see also Alberta Law Reform Institute, supra note 129 at 41. See Mark R. Smith \& Colin Feasby, "The Effect of Bankruptcy on CO\&O, Unit and Pooling Agreements” JV Views (Summer 2001) 15.

McLaren wrote: "The rationale for s. 32 is that where a lien is created through work done to the Collateral that is intended to enhance or preserve its value, it ought to have priority over a prior Secured Party”: supra note 110 at 208. 
security of secured lenders. Is the Operator-Joint-Operator relationship not the very type of relationship that s. 32 is designed to protect? Why should priorities change, and the protection of s. 32 be withdrawn, simply because the lien holder has the good sense to have the lienor sign a contract?

Justice Horner's judgment in Caribou on this point is very succinct; "I agree with the reasoning of Justice Romaine as to the interpretation of s. 32 and believe it is appropriate that an exception to the residual priority rule in s. 35 be strictly construed.”136 Justice Romaine, in Kalta, had addressed the argument that s. 32 should be construed in accordance with the plain meaning of its words, and rejected it, saying in part:

\footnotetext{
While there may be valid policy reasons to exempt holders of statutory non-consensual liens from the PPSA and its requirements, I am not persuaded that they exist with respect to consensual contractual liens that create, in effect, a security interest.... [T]he term "lien" is no longer a term of art ... [i]ts usage has broadened to include consensual security interests, and to cover interests created by sophisticated parties in intricate and thoroughly negotiated commercial contracts. The same policies should not apply to each use of the term, and the special status afforded to holders of statutory non-consensual liens should not necessarily be extended whenever parties choose to label an interest they create with the term "lien." 137
}

For now, the s. 32 question appears to be settled. Even if s. 32 had been held to apply to the CAPL lien, that would help Operators only to the extent of personal property. Section 32 of the PPSA would not affect the lack of registration of the CAPL lien under the LTA, in relation to freehold land, or under the $L P A$, in relation to Crown land. The scenario in which an Operator has s. 32 priority as to the production and proceeds, while a bank has $M M A$ priority to the lease, is nevertheless interesting to consider.

Finally, Operators may have relationship liens. The judgment in Caribou does not tell us whether those relationship liens might have access to s. 32 of the PPSA. Clause 505(b) of the 1990 CAPL states that the remedies it provides are not a limitation on the Operator's rights at law or in equity.

Arguably, the Operator may have three types of meaningful relationship liens, each of which may have the benefit of s. 32 of the PPSA.

(1) A general lien can arise by contract or by trade custom. ${ }^{138}$ If one was able to establish that such a lien exists alongside the CAPL lien, and that the general lien arose independently of the contract, then that lien could have priority over a perfected or unperfected security interest via s. 32 of the PPSA. We must caution that establishing such a general lien would be an uphill battle. The question, however, has not been decided in the context of the Alberta oil and gas industry and American courts seem to have recognized an Operator's lien as being a general lien. Recall also our earlier

See Kalta, supra note 125 at paras 12-14. Justice Romaine's interpretation might be narrower than that of the Alberta Law Reform Institute, in that Romaine J. seems to restrict the application of s. 32 to statutory liens, while the report may simply exclude contractual liens (with the possible exception of general liens implied into contracts) from s. 32: see supra note 129 at 40-42. See supra note 133 and accompanying text. 
discussion of the treatment of Operator's liens in the Canada Petroleum Resources Act and in the Nova Scotia and Newfoundland Accords. ${ }^{139}$ In Alberta, the term "general lien" has been used in court in attempts to extend the registration period for builders' liens, but not in the context of the PPSA. ${ }^{140}$

(2) The Possessory Liens Act ${ }^{141}$ provides certain parties with a "particular" lien over all chattels on which the lien holder has expended money, labour, or skill, provided that the lien holder maintains actual or constructive possession. ${ }^{142}$ Arguably, an Operator has a possessory lien under the PLA. This appears to be the type of non-consensual lien, as contemplated by Cuming and Wood. ${ }^{143}$ However, the PLA does not apply to proceeds, and as such the Operator's possessory lien, even if protected by s. 32 of the PPSA, may not be of much practical use to an Operator. The Operator's possession or constructive possession of production is generally very brief. That said, the possessory lien argument might work in respect of the Joint-Operator's interest in onsite equipment.

(3) Operators may also have a builders' lien under the $B L A{ }^{144}$

b. The Personal Property Security Act and the Judicature Act — Assignment of Debts

We now turn to an additional area concerning the workings of the PPSA in the context of Operator's liens. Clause 505(b)(v) of the 1990 CAPL gives the Operator an "immediate and automatic assignment” of the proceeds of the Joint-Operator's share of petroleum substances, and provides that service of a copy of the Operating Procedure upon a purchaser of such petroleum substances constitutes a "written irrevocable direction" by the Joint-Operator to pay the production sale proceeds to the Operator, up to the amount owed by the JointOperator to the Operator. ${ }^{145}$ How do these provisions square with the statutory rules that govern the assignment of choses in action? And what are those rules?

The assignment of proceeds in cl. 505(b)(v) of the 1990 CAPL (which has been significantly modified in the 2007 CAPL) brings into play ss. 41(5) and (6) of the PPSA and also arguably, s. 20(1) of the Judicature Act. ${ }^{146}$ Sections 41(5) and (6) of the PPSA deal with the effect of notice of an assignment of "either an intangible or chattel paper."147 Section 20(1) of the Judicature Act is a little different: it deals with the effect of notice in writing of an assignment of a chose in action where it is an "absolute assignment made in writing ... and not purporting to be by way of charge only." "148 The conflict provision set out in s. 74(2)

See Part V.B.1. See also Re Merrill Engineering Ltd., 2004 BCSC 493, 2 C.B.R. (5th) 301; Pettifer, supra note 12 at 104-105.

140 See Re Gauntlet Energy Corp., 2003 ABQB 1014, 351 A.R. 197 at paras. 9-20; Schlumberger Holdings (Bermuda) Ltd. v. Merit Energy Ltd., 2001 ABQB 34, 288 A.R. 269 at paras. 13-32, rev'd 2001 ABCA 190, 299 A.R. 171.

141 R.S.A. 2000, c. P-19 [PLA]

142 Ibid., ss. 2, 5-6.

143 See supra note 127 and accompanying text.

144 See supra note 9; see also Part V.C., below.

1451990 CAPL, supra note 1, cl. 505(b)(v).

$146 \quad$ Supra note 48.

147 PPSA, supra note 44, s. 41(5).

148 Judicature Act, supra note 48, s. 20(1). 
of the PPSA appears to have the result that ss. 41(5) and (6) of the PPSA govern questions relating to the "notice" and the "assignment" set out in cl. 505(b)(v) of the 1990 CAPL, ${ }^{149}$ and that s. 20(1) of the Judicature Act would be applicable only if and to any extent that ss. 41(5) and (6) of the PPSA are not applicable in a particular situation.

Prior to the enactment of the PPSA, the priority of the cl. 505(b)(v) assignment relative to a competing assignment of production sales proceeds would have been decided on the basis that the first to give notice would prevail. Service of notice as soon as possible was important because the timing of notice would determine priority. (The "written irrevocable direction," or “directives to pay," was probably a practical tool as opposed to a response to a legal requirement.) However, the PPSA changed that and priority is now governed by the priority scheme laid out in the PPSA. The combined effect of PPSA, ss. 12, 19, 20, 24, and 35, together with ss. 41(5) and (6), upon cl. 505(b)(v) of the 1990 CAPL seems to be that (a) if the Operator has not registered its cl. 505(b)(v) assignment under the PPSA, then that assignment is subordinate to all security interests that are so registered, and (b) serving notice of the cl. 505(b)(v) assignment upon account debtors will not change that, and indeed does not play a role in priority. Notice is now merely part of the realization process; notice obliges and entitles the third party to pay the assignee (subject to the assignee's relative priority position). The Operator's entitlement to serve notice on the account debtor is laid out in s. 57 of the PPSA. Service of notice upon a third party will also curtail that party's legal and equitable rights of set-off, ${ }^{150}$ but it is rare today for secured lenders to serve notice of assignments on parties such as Operators until the lenders begin to realize on their security following a default in their loan agreement.

\section{THE OPERATOR'S BUILDERS' LIEN}

As mentioned above, one of the relationship liens that may be available to an Operator is a builders' lien under the $B L A .{ }^{151}$ Builders' liens can be registered at either the LTA, in the case of freehold lands, or the $M M A$, in the case of Crown lands. They are not registrable under the PPSA. In Coachlight Resources Ltd. v. Duce Oil Ltd., ${ }^{152}$ the Saskatchewan Court of Queen's Bench granted an Operator's claim to a builders' lien against a Joint-Operator. Based on the decision in Blue Range, ${ }^{153}$ an Operator's lien should be considered to be a "prevenient arrangement” for BLA purposes, with the result that the Operator's builders' lien may encumber lands and minerals to the extent of all debts dating back to the commencement of operations under the Operating Procedure, provided that the builders' lien is registered within 90 days after the completion of the last operation. ${ }^{154}$

1990 CAPL, supra note 1, cl. 505(b)(v). Corbett, supra note 12 at 29-30, discusses priority issues relating to the cl. 505(b)(v) assignment extensively. He focuses upon the requirement that an assignment be "absolute" in order to have the benefit of s. 20(1) of the Judicature Act and concludes that the cl. 505(b)(v) assignment is probably not "absolute," and on that basis, rather than on the basis of the PPSA, s. 74(2), concludes that the effect of notice of the cl. 505(b)(v) assignment is governed by the PPSA and not the Judicature Act.

PPSA, supra note 44, s. 41(2)(b).

See Part IV.A., below.

(1999), 181 Sask. R. 125 (Q.B.).

Re Blue Range Resource Corp., 1999 ABQB 873, 254 A.R. 103 at paras. 3-8 [Blue Range]. Ibid. 
This sounds good in theory. However, attempting to use a builders' lien under the $B L A$ to recover debt owed to a 1990 CAPL Operator may be awkward given the practical realities of the oil and gas industry.

In the oil and gas industry context, there is some doubt as to what specific assets qualify as "improvements" for the purposes of the BLA, such that expenditures and work in relation to them would give rise to a builders' lien. ${ }^{155}$ For example, costs relating to a non-fixture might not qualify. It also seems questionable whether operational costs and related activities, as opposed to capital costs and related activities, are costs and activities "on or in respect of an improvement." ${ }^{156}$ If costs and activities do not qualify, they will not give rise to a builders' lien.

Further, it appears that an Alberta builders' lien does not extend to proceeds. ${ }^{157}$ Although s. 6 of the BLA specifically provides for attachment in the context of the Alberta oil and gas lease and that such attachment extends beyond the land to the production once severed, attachment to the production alone but not to proceeds provides little value. Any buyer of production in the ordinary course will take free and clear of any such lien under s. 30 of the PPSA. Section 30 of the PPSA provides that a buyer of goods in the ordinary course of business takes free and clear of any perfected or unperfected security interest given by the seller, whether or not the buyer has knowledge of the interest, and s. 74(2) of the PPSA subjugates the BLA to the PPSA. Finally, unless the builders' lien is registered prior to the bank's mortgage under the LTA or its security interest under the $M M A$, it is likely that the builders' lien ranks behind the bank's security insofar as real property interests are concerned. ${ }^{158}$

\section{SUBORDINATION}

The unregistered Operator's lien will likely lose any priority contest with registered security, whether one considers Crown or freehold property or any kind of personal property, on the basis of the priorities established by the applicable statutory scheme. Even the registered Operator's lien will lose to a prior registered security interest. Nevertheless, a party that has statutory priority can lose priority or give it away. This can occur with the consent or agreement of the senior creditor by way of an agreement to subordinate, or as a result of the principle of equitable subordination.

See $B L A$, supra note 11 , s. $1(\mathrm{~d})$.

Ibid., s. 6(1)(a).

The Builders'Lien Act, S.S. 1984-85-86, c. B-7.1, purports to extend a lien to the proceeds of a mineral sale. Section 22, combined with ss. 6-7, may give the lien holder priority over such proceeds. In Saskatchewan, therefore, a builders' lien may be a more effective remedy for Operators than in Alberta. Section 22(2) [emphasis added] reads as follows: the lien given by subsection (1) is also a lien on:

(e) the mineral when severed and recovered from the land while it is in the hands of the owner, and to the proceeds of the mineral and to the amounts to be paid in lieu of the proceeds of the mineral to the owner by a person that operates the mine, oil well or gas well.

No such wording appears in the Alberta Act.

For a detailed discussion of the BLA in the context of the oil and gas industry, see Keith T. Smith \& Drew E. MacIntyre, “Builders' Liens in the Oil and Gas Industry" (Paper presented to the Insight Educational Services Seminar, Calgary, 21 October 1991) in Insight Educational Services, New Developments in Builders’ Liens in Alberta (Mississauga: Insight Press, 1991). 


\section{CONSENSUAL SUBORDinAtion}

a.

PPSA, MMA, LTA, and LPA

Here again we must keep in mind the difference between personal property and real property. For personal property, the PPSA sets out the statutory priority scheme but also expressly recognizes the concept that the senior ranking security interest holder may subordinate to another party. Section 40 of the PPSA reads as follows:

A secured party may, in a security agreement or otherwise, subordinate the secured party's security interest to any other interest, and the subordination is effective according to its terms between the parties and may be enforced by a third party if the third party is the person or one of a class of persons for whose benefit the subordination was intended. ${ }^{159}$

Section 40 does not require that the subordination be registered and extends its benefit to third parties. It removes any need for the third party to address third party beneficiary rules. Keeping in mind that this relates only to personal property, how might this be of use to an Operator? Obviously, priority over the produced substance or the proceed of its sale can be useful, but what of the underlying interests in land?

When we turn to real property, we find that there is no section in the MMA or LTA to correspond to s. 40 of the PPSA. Section 107 of the LTA provides that a mortgagee or other encumbrance holder may postpone its rights by filing a postponement, and s. 96(1)(c) of the $M M A$ provides for the registration of a "notice of the postponement of a registered security notice." ${ }^{160}$ However, those provisions are quite different from s. 40 of the PPSA. They do not contemplate third party beneficiaries and they require that the postponement be registered in order to have any effect.

Section 64(3) of the LPA, however, provides as follows: "Sections 18, 40, 68 and 72 of the Personal Property Security Act and Part 4 of that Act, other than sections 44(2), 49 and $50(1)$ to (5) and (8), apply with all necessary modifications to registrations under this section." "Als1 Also, s. 64(8) of the LPA provides that: "This section is subject in all respects to the Land Titles Act and the Mines and Minerals Act, and the priority of any interest registered or filed under either Act shall be determined pursuant to that Act."162

By virtue of s. 64(3) of the $L P A$, the recognition of subordination set out in s. 40 of the $P P S A$ is extended to real property registrations under the $L P A$, but ultimately the LTA or $M M A$ still govern. How do we read s. 40 of the PPSA with reference to the LTA and MMA respectively? Does s. 64(8) of the $L P A$ allow for subordination in relation to real estate (freehold or Crown) pursuant to s. 40 of the PPSA only in circumstances where priority is not governed by either the LTA or the MMA? 
The LTA appears to contain a complete priority scheme that does not recognize unregistered interests. Some interesting questions arise here. Does a s. 40 PPSA subordination relating to land involve a conveyance of an interest in land, such that it must deal with the Statute of Frauds and s. 53 of the LTA ${ }^{163}$ Does a s. 40 PPSA subordination involve an alteration to the LTA priority scheme, or is it a statutory recognition of a contractual (or other) consequence that is enforceable outside of that scheme? Does s. 64(8) of the LPA make it clear that the s. 40 PPSA subordination concept has no application to priorities otherwise established by the LTA?

The analysis and questions with respect to the $M M A$ are a little different. As explained in Part V.B, above, the MMA appears to leave a door open under s. 95(4)(d) that triggers the operation of the LPA; the relative priority of an Operator's lien that is acquired before the $M M A$ registration of a competing security interest is governed by the $L P A$. Does this mean that s. 64 of the LPA also applies, such that in turn s. 40 of the PPSA also applies in that limited circumstance? If some form of subordination agreement exists, this might be a useful argument in relation to Crown lands for an Operator in a situation in which the Operator's lien arose first in time, but the bank registered at the LPA before the Operator did.

All of the s. 40 PPSA cases of which we are aware involve personal property and so do not assist us in answering the foregoing questions. A possible exception is Dynex, ${ }^{164}$ in which the subject matter was an overriding royalty the trial judge proceeded on the premise that an overriding royalty was not an interest in land, and so examined subordination pursuant to s. 40 on that basis. The Court of Appeal subsequently held that royalty to be an interest in land, and thus did not need to examine whether the trial Court's analysis of subordination would still apply. ${ }^{165}$

\section{b. The Case Law}

The courts have addressed subordination agreements in a number of debtor-supplier situations. Based on those court decisions, and depending on the wording of a particular security agreement, there seems to be plenty of ammunition with which to construct an argument that a CAPL Operator should have priority over a secured lender on the basis of consensual subordination. In the context of the Operator's lien, there are parallels between the relationship between a debtor and its suppliers and the relationship between a JointOperator and its Operator.

Very briefly, and as Kentigern Rowan discusses, the courts have held that a subordination clause must be clear and unambiguous in its intent to effect a subordination. However, no

163 See Part V.B.2, above.

164 Bank of Montreal v. Dynex Petroleum Ltd. (1995), 39 Alta. L.R. (3d) 66 (Q.B.), rev’d 1999 ABCA 363, 255 A.R. 116 [Dynex].

165 The important cases in this area include: Euroclean Canada Inc. v. Forest Glade Investments Ltd. (1985), 49 O.R. (2d) 769 (C.A.), leave to appeal to S.C.C. refused, 19365 (6 March 1985); Sperry Inc. v. Canadian Imperial Bank of Commerce (1985), 50 O.R. (2d) 267 (C.A.); Chiips Inc. v. Skyview Hotels Ltd. (1994), 155 A.R. 281 (C.A.) [Chiips]; Engel Canada Inc. v. TCE Capital Corp. (2002), 34 C.B.R. (4th) 169 (Ont. Sup. Ct. J.) [Engel]; Dynex, ibid. The main s. 40 PPSA cases as well as others are addressed in some detail in Kentigern A. Rowan, "Judicial Comment on Priority and Subordination" (Paper presented for the Legal Education Society, 5 November 2003) [unpublished]. 
“'magic' words” are needed. ${ }^{166}$ The courts will admit extrinsic or parol evidence in an examination of the parties' intention and, as the Court stated in Engel, "clauses must be interpreted using the common sense plain meaning of the words, having regard to the practicalities of a commercial enterprise." ${ }^{\text {"67 }}$ With reference to the standard practice in bank security of including an Operator's lien within a list of permitted encumbrances, the following comment in the Engel decision is of particular interest: "Allowing the purchase of specified encumbered assets without granting priority in the encumbrance appears to be a hollow right that does not make commercial sense unless subordination is implicit."168

Nevertheless, arguments based on the principles set out in Chiips ${ }^{169}$ and Engel may be difficult to make in the context of an Operator's lien if the written agreements between the secured lender and the Joint-Operator contain language that expressly negates any intention to subordinate. In recent years, such clauses have become commonplace and various court decisions have relied on them to find that there was no subordination. ${ }^{170}$

\section{2. "EQUiTABLE SUbORDINATION"}

As Alison Manzer and Howard Ruda observe, equitable subordination is a remedy based on the concept that the court can subordinate all or part of a creditor's claim in a bankruptcy and insolvency proceeding if the creditor is "engaged in inequitable conduct that has resulted in such creditor acquiring an unfair advantage over or caused injury to other creditors." 171 This remedy, they continue, "may be invoked where one creditor, through fraud or other wrongful conduct, has increased the recovery on his or [her] claim, or enhanced the prospect for such recovery at the expense of other creditors of the common debtor."172

Several lines of cases in Canada expressly reject the doctrine of equitable subordination, while some decisions acknowledge that it is available. However, Manzer and Ruda note that:

\footnotetext{
The Supreme Court of Canada has however given some guidance as to criteria which might lead to the application of the doctrine of equitable subordination, without expressly determining whether the doctrine should be formally adopted into Canadian law. It stated that if a claimant is engaged in some type of inequitable conduct which ... conferred an unfair advantage on the claimant, and the equitable subordination of the claim is not inconsistent with the provisions of the bankruptcy statute, then there may be circumstances in which the doctrine could be applied. ${ }^{173}$
}

The availability of the doctrine seems to be in some doubt.

If available, the doctrine of equitable subordination seems to have clear application to the plight of the Operator who advances its own money to increase the value of the Joint-

166 Rowan, ibid. at 11.

$167 \quad$ Engel, supra note 165 at para. 48.

Ibid. at para. 53.

169 Chiips, supra note 165.

170 See e.g. Caribou, supra note 123.

171 Alison Manzer \& Howard Ruda, Asset Based Lending in Canada: Canadian Primer on Asset Based Financing (Markham: LexisNexis Canada, 2008) at 304.

172 Ibid. at 305

173 Ibid. at 305-306. 
Operator's property only to have the bank take it all, and might even provide a way past a clause that expressly negates any intention to subordinate to Operators' liens. ${ }^{174}$

Arguments of consensual and equitable subordination were advanced in the Caribou case; however, the Court rejected these arguments, partly on the basis of a clause expressly negating subordination. Justice Horner stated:

Firstly, the permitted encumbrance clause is not broad enough on its own to stand the interpretation Bearspaw would give it. Section 17 of the Brookfield loan agreement deals with the meaning of "permitted encumbrances" in the document and makes it clear that it is not to be construed as a subordination agreement. There is nothing further on these facts that would require the equity of the Court to intervene, even if it had the jurisdiction. The Operators in the oil and gas industry have the wherewithal to retain counsel and become advised as to their position in the event of an insolvent participant. They can register their interests at the Personal Property Security Registry, but choose not to for business reasons. They take a risk and sometimes they lose. Such is the business world. ${ }^{175}$

This passage is instructive, if somewhat alarming, from the perspective of an Operator or Processor, even if the decision was fact specific.

Overall, the common practice of not registering Operators' liens, the exclusion of the Operator's lien from the purview of s. 32 of the PPSA, and the practice of including wording in security documentation to negate subordination to permitted encumbrances, all render Operators vulnerable in the secured creditor world. The Caribou judgment might even suggest that Operators should beware of entering into 1990 CAPL agreements with JointOperators who may become insolvent, and that the unregistered Operator might lose even an argument of equitable subordination if it has not registered its lien under the PPSA. ${ }^{176}$

\section{E. THE BANK ACT}

A detailed discussion of Operator's liens in the context of Bank Act security is beyond the scope of this article. Briefly, s. 426 provides the basis for taking Bank Act security in relation to "minerals" and "hydrocarbons." ${ }^{177}$ Although s. 426 of the Bank Act sets out certain priority rules, s. 426(8) makes it clear that Bank Act security does not take priority over an interest that is registered "in the proper ... office" with respect to that property unless the Bank Act security was registered first in time. The provincial registration and priority schemes discussed above remain intact. ${ }^{178}$

We query whether the cases Albemarle Supply Co. v. Hind \& Co., [1928] 1 K.B. 307 (C.A.); Bank of Montreal v. Guaranty Silk Dyeing and Finishing Co. Ltd., [1935] O.R. 493 (C.A.); Continental Bank of Canada v. Henry Mogensen Transport Ltd. (1984), 54 A.R. 27 (Q.B.) may provide a basis to argue that subordination to a lien can result from the conduct of the secured party.

See Part V.B.3, above.

Bank Act, supra note 45, s. 426.

Ibid. We also refer the reader to the discussion of Bank Act security at the end of Part V.B.1, above. 


\section{Vi. Practical Observations}

\section{A. To REgister OR NOT To REgISTER}

The Operator must deal with several registration schemes and registries. An Operator can register its lien against personal property as a security interest under the Personal Property Registry; depending on whether the joint lands are Crown or freehold, as a land charge pursuant to the LPA at the Personal Property Registry; as an equitable interest under the LTA; or even, perhaps, as a builders' lien under the MMA or the LTA.

It is current industry practice not to register Operators' liens at any of these registries. In fact, an Operator's registration will often cause a commotion because registration is taken as an indication that the Joint-Operator has committed a breach or is in financial difficulty. This is particularly true when the Joint-Operator is involved in an attempt to arrange new financing or sell its interest and the third party's lawyers find the Operator's registration in the course of their due diligence searches.

From a legal perspective, it seems clear that Operators should register their Operators' liens under the LTA, LPA, and PPSA when the circumstances warrant. However, there are many practical arguments against registration, and especially against registration in respect of all Joint-Operators and all land situations. In the end, an Operator must weigh the circumstances and make a business decision.

Operators will make their own decisions. The following are some of the arguments on each side of the question, which we hope will help to identify the circumstances in which registration is the right call.

\section{THE CASE FOR REGISTRATION}

1. Registration in and of itself is inexpensive.

2. Even if a registered Operator ranks behind the registered bank, the registered Operator has at least secured its status as a secured creditor in a bankruptcy proceeding and as against any unsecured creditors or subsequently registered secured creditors. If the liened assets have sufficient value to pay off the bank, this will be valuable. If the Operator does not register, the Operator risks being subordinated to subsequent security interests, and, in the personal property context of s. 20 of the PPSA, being categorized as an unsecured creditor in the event the Joint-Operator goes bankrupt. As noted above, a similar result might follow with respect to freehold land on the basis of s. 53 of the $L T A .{ }^{179}$

3. Even if a bank has registered first, there may be flaws in the bank's security or registration. 
4. Things change. The Joint-Operator may subsequently change lenders or sell its interests to another party. The first lender may be paid out, rather than assign its security position. A new lender's security may come into existence (and be registered) after the Operator's registrations and will rank behind the latter.

5. With reference to the Joint-Operator's personal property, in the event of a sale of the Joint-Operator's interest to a new owner, and irrespective of bankruptcy or the CCAA, the Operator will have protected its security interest in the sale proceeds, and will remain secured in the sold asset as against the successor in interest to the JointOperator (provided that the Operator files financing change statements as required to amend its security interest and its land charge to reflect the transfer of ownership). ${ }^{180}$

6. In the event of a sale of the Joint-Operator's interest, even if the successor in interest has previously granted a floating charge or general security agreement encompassing the joint lands that was registered prior to the registration of Operator's lien, the Operator's registered security will rank ahead of that of the new bank (provided that, with respect to personal property, the Operator files a financing change statement within 15 days of acquiring knowledge of the transfer).

7. The Operator who does not register and then loses might open itself up to an argument by the other Joint-Operators that its failure to register constituted gross negligence, causing the Operator to lose its entitlement to indemnification and contribution under cls. 401 and 402 of the 1990 CAPL.

\section{The CASE Against Registration}

1. Many enforcement scenarios do not involve a contest with the Joint-Operator's bank, or even its insolvency, but rather involve disputes between a solvent Operator and a solvent Joint-Operator. In these cases, priority and registration are not at issue.

2. Registration is unorthodox, and there may be hidden costs in defending the registration or responding to demands for particulars under s. 50 of the PPSA once the registration is filed.

3. In cases which do involve a priority contest between Operator and a bank, the race may be over before the Operator enters the picture and registration will be a wasted effort. All-encompassing bank security will already be registered against JointOperators at the Personal Property Registry and at the Land Titles Office before the Operating Procedure is signed and before the Operator has any opportunity to register. Unless the value of the assets at the time of bank realization is materially higher than the bank debt, the bank will take everything that is available. Only on subsequent 
transfers of the Joint-Operator's interest can the Operator really hope to gain priority by virtue of its registration. ${ }^{181}$

4. Considered on an asset-by-asset basis, the priority achieved by registering under the PPSA and BLA may not apply to the entirety of the personal and real property encapsulated in the Joint-Operator's working interest.

5. The remedies protected by registration may not meet the practical and time sensitive requirements of the Operator at the time the Joint-Operator defaults, and may be costly to enforce.

6. Operators should instead focus on prevention via the advance of costs under cl. 503 of the 1990 CAPL. It may be more important and practical to exercise the Operator's right to require cash in advance or, if available, to balance accounts via joint venture billings. If such procedures are used properly, the CAPL lien is not important, and so why invest time and money to perfect it?

7. Set-off rights will likely be available regardless of registration, even after a bankruptcy (see Part VI.B, below). Where there are debts that may be set-off, the Operator's exposure to significant arrears can be kept to manageable levels and it may not be necessary to protect other remedies that are vulnerable to the registration priority rules.

8. Although for PPSA purposes the unregistered Operator will not be considered to be a secured creditor of personal property in a bankruptcy situation, that is not true with respect to real property.

9. Even if the Operator ranks second due to non-registration, it may overcome that disadvantage by means other than registration. As discussed above, the bank or other secured creditor may subordinate its interest to that of the Operator by agreement or conduct.

10. Registration is important only when the Joint-Operator becomes insolvent, or the bank moves on its security, which happens rarely. The size and strength of individual JointOperators will often make this a remote possibility.

\section{B. SET-OFF}

The Operator may have rights of set-off both under the CAPL lien and independently of contract, under legal and equitable principles, irrespective of the registration of the CAPL lien. These rights survive insolvency and bankruptcy, since they are preserved under both the 
$C C A A^{182}$ and the BIA. ${ }^{183}$ CAPL set-off rights may be useless after a prior ranking registered lender realizes on its security, but they can be valuable until that time, and in other scenarios.

Clause 505(b)(iii) of the 1990 CAPL allows the Operator to set-off amounts owing to it against amounts due or accruing due to the Joint-Operator, whether under the Operating Procedure or any other contract between them. However, the cl. 505(b)(iii) right of set-off may be employed only after the Joint-Operator has failed to pay a valid invoice within the time period prescribed, and only to the amount of such a failure, and the Operator must have complied with the prerequisites of enforcement set out in cl. 505(b) of the 1990 CAPL.${ }^{184}$ Setoff under cl. 505(b)(iii) of the 1990 CAPL is limited and slow-acting. Further, this remedy may not be practically effective where the Operator does not owe the Joint-Operator as much money as the Joint-Operator owes it, which is often the case where the Joint-Operator is taking its share of production from the joint lands in kind.

However, prerequisites aside, the Operator's CAPL lien contractual right of set-off is an attractive remedy. Contractual CAPL set-off may be superior to both legal and equitable rights of set-off because its use is not subject to considerations of mutuality, prejudice to other creditors, or knowledge of intervening assignments. Considerations of prejudice and knowledge are applicable only to equitable set-off, and not to contractual set-off. ${ }^{185}$ Contractual set-off is enforceable according to the terms of the contract. Further, in the personal property context, the Operator's right to set-off is preserved as against an assignee of debts by s. 41(2)(a) of the PPSA ${ }^{186}$ Despite its apparent appeal, the authors are not aware of any case confirming or discussing a particular application of an Operator's contractual right of set-off under the CAPL lien in the face of a secured party's realization. ${ }^{187}$

See CCAA, supra note 47, s. 21 which reads: "The law of set-off or compensation applies to all claims made against a debtor company and to all actions instituted by it for the recovery of debts due to the company in the same manner and to the same extent as if the company were plaintiff or defendant, as the case may be.” See also Re Blue Range Resource Corp., 2000 ABCA 200, 261 A.R. 162 [Blue Range 2].

See BIA, supra note 46, s. 97(3), which reads as follows:

The law of set-off or compensation applies to all claims made against the estate of the bankrupt and also to all actions instituted by the trustee for the recovery of debts due to the bankrupt in the same manner and to the same extent as if the bankrupt were plaintiff or defendant, as the case may be, except in so far as any claim for set-off or compensation is affected by the provisions of this Act respecting frauds or fraudulent preferences.

See Powermax, supra note 28 at para. 129.

See Canada Trustco Mortgage Co. v. Sugarman (1999), 179 D.L.R. (4th) 548 at para. 19 (Ont. C.A.); Pioneer Grain Co. v. Goy, 2005 FC 530, [2005] 4 F.C.R. 687 at paras. 18-20.

See the PPSA, supra note 44, s. 41:

(1) In this section, "account debtor" means a person who is obligated under an intangible or chattel paper.

(2) The rights of an assignee of collateral that is either an intangible or chattel paper are subject to

(a) the terms of the contract between the account debtor and the assignor and any defence or claim arising out of the contract or a closely connected contract, and

(b) any other defence or claim of the account debtor against the assignor that accrues before the account debtor has knowledge of the assignment,

unless the account debtor has made an enforceable agreement not to assert defences or claims arising out of the contract.

Note that the word "knowledge" is included in the wording of s. 41(2)(b), while not in that of s. 41(2)(a). We interpret this to mean that contractual rights of set-off are preserved irrespective of the account debtor's knowledge of the assignment. See also Cuming \& Wood, supra note 120 at 387-88. We query whether the timing of the assignment influences the application of s. 41(2)(a) of the PPSA. See Corbett, supra note 12 at 28. 
The leading case on equitable and legal set-off is Telford. ${ }^{188}$ Legal set-off will, in most cases, be foreclosed to the Operator by an assignment of debts (such as the Joint-Operator has usually provided to the secured lender) because such assignment destroys the necessary "mutuality." 189

The Operator may also have equitable rights of set-off independently of the 1990 CAPL. Equitable set-off, though not requiring mutuality, requires that the interests of other secured creditors be taken into account and that the courts must not, in granting an equitable remedy, produce an inequity to another party. Further, any claim of equitable set-off may be precluded where the Operator has or ought to have knowledge of the intervening assignment. ${ }^{190}$ In the context of the PPSA, s. 41(2)(b) effectively codifies equitable set-off, although there may be differences under the PPSA and under common law as to the meaning of "knowledge."191

As a final note on set-off, it is important to keep in mind that in order to exercise any right of set-off following a CCAA order in respect of a Joint-Operator, the Operator will likely need court approval. CCAA orders commonly address set-off and preclude further set-off without court approval. ${ }^{192}$

\section{SET-OFF AND JOINT VENTURE BILLING}

It is very common practice for Operators to carry out joint venture billing for all wells in which an Operator and a particular Joint-Operator share interests on a cumulative net basis, regardless of the number of different 1990 CAPL agreements involved. This "netting” does not appear to be an authorized set-off under cl. 505(b)(iii) of the 1990 CAPL because the "netting off" is done on a monthly basis, often before the subject costs are due, let alone overdue, and in the absence of the issuance of any notice of default. In fact, this action does not seem to be authorized anywhere in the 1990 CAPL, including the 1996 PASC. Clause 102 of the 1996 PASC simply calls for monthly bills and payment within 30 days after each bill. It seems to contemplate separate billing for each 1990 CAPL agreement. No mention is made of accumulating all bills on all joint venture wells, let alone setting them off against each other to give the Operator immediate payment of the bills for one well out of the proceeds of production from another before the occurrence of a default and the expiry of a notice of default period.

Yet joint venture billing is a common practice, Joint-Operators usually acquiesce to it, and given a correct relationship of joint revenues to joint costs, the practice will usually prevent the growth of a Joint-Operator's arrears to a significant sum. Therefore, this is a very practical means of Operator protection existing outside of the CAPL lien. But is it legitimate? Can a Joint-Operator object and put a stop to it? Is joint venture billing justified by common law rights of set-off that exist in tandem with the cl. 505(b)(iii) set-off?

\footnotetext{
188 Holt v. Telford, [1987] 2 S.C.R. 193 [Telford].

189 Ibid. at para. 25.

$190 \quad$ See Kalta, supra note 125 at para. 16.

191 See supra note 186.

$192 \quad$ See Blue Range 2, supra note 182.
} 
The discussion of set-off in the context of an Operator in the Powermax decision - in particular, the recognition that the Operator is a fiduciary - seems to indicate that an Operator cannot exercise any legal or equitable right of set-off in the absence of either an agreement that permits it or the consent of the Joint-Operator. ${ }^{193}$ An argument to that effect appears to have been made in Kalta, although it is not clear that the argument was made in the context of joint venture billings. In Kalta, the Operator submitted that it was entitled to apply equitable set-off. The Operator submitted that it met all of the prerequisites set out in Telford, and that it would be "manifestly unjust" to not allow set-off. ${ }^{194}$ We will not attempt here to apply the Telford decision to the practice of customary joint venture billing, but it does seem unlikely that an Operator could make a case that it would be "manifestly unjust" to deny it the right to conduct joint venture billing on a cumulative net basis. It is also interesting to note that, in Kalta, the Operator was found to have breached the processing agreement by making a unilateral accounting reallocation, and as a result could not succeed in its claim for an equitable remedy.

An alternative defence of joint venture billing might be found in the law of estoppel. Where joint venture billing has been a long standing practice, the Operator could make this argument, but in order to succeed, the Operator would need to establish detrimental reliance - which it might be able to do if it failed to issue cash calls because it had been led to rely on collection through joint venture billing. An argument based on acquiescence seems to carry more weight.

Overall, an Operator may not have a valid right to net bill in this way and an Operator that is tempted to effect a set-off without taking the prerequisite steps and against the objections of the Joint-Operator should beware that doing so may expose it to an action against it for breach of cl. 606 of the 1990 CAPL. Clause 606 requires the Operator to distribute a JointOperator's income or proceeds of production forthwith. In addition, the Operator could face an action for breach of trust pursuant to cl. 507 and an action to replace it as Operator under cl. 202(b)(ii).

To the extent that joint venture billing on a cumulative net basis is permitted only because the Joint-Operator's silence may be taken as consent, it seems reasonable to suggest that a Joint-Operator could expressly revoke that consent at any time, at least as to billings effected after notice of such revocation.

\section{QUESTIONABLE END RUNS AND SHORTCUTS}

The Operator often faces a critical need to move quickly when seeking to collect funds from a defaulting Joint-Operator, especially when there are legitimate concerns for the solvency of either the Operator or Joint-Operator. This may contribute to a decision by some Operators to ignore, or attempt to short-circuit, the technical requirements of giving notice of default, waiting out the cure period, and providing an additional ten days notice of the 
"time and place" of the sale of a Joint-Operator's oil before moving under any of cls. 505(b)(iii) through (vi). While the Operator can charge interest and withhold "information and privileges" as soon as the Joint-Operator is in arrears, those actions may not pay any bills. $^{195}$

\section{The SPLit NoticE}

When the Joint-Operator is not taking its share of production in kind, and the Operator is selling the Joint-Operator's share of production on its behalf, or buying that share of production, under the procedures laid out in article VI of the 1990 CAPL, the JointOperator's share of production revenues flows through the Operator's hands. This puts the Operator in a position to set-off amounts (which, in the Operator's opinion, the JointOperator owes to it) against the Operator's share of revenues, and, by a simple accounting entry in joint venture billings, to collect the debt - at least to the extent that production revenues are available. The Operator can aggregate debts and revenues relating to a number of different wells, properties, and joint operating agreements with a particular Joint-Operator to achieve such collection on a company-wide basis. This practice is not without risk, as we discussed above, but it puts money in the Operator's hands.

The Operator is not in such a fortunate position when the Joint-Operator takes its share of production in kind. However, experience has shown us that, even in these cases, some Operators will manipulate things to suit their purposes. Some manipulations seem to venture very close to breach of contractual or even fiduciary duties under the 1990 CAPL. ${ }^{196}$

To the extent that these actions might be breaches of obligations under the $1990 \mathrm{CAPL}$, and regardless of whether they might be separately or independently justified by common law rights outside of the 1990 CAPL, they do expose the Operator to an action for damages and potential replacement under cl. 202(b)(ii). In addition, taking these steps may not be in an Operator's own best interests. The enforcement of an Operator's lien can (1) put a JointOperator offside its bank covenants and so lead directly to at least the risk of bank enforcement and a priority fight (which the Operator may lose); and (2) cause the JointOperator to commit downstream defaults and thus expose the Operator to disputes involving downstream creditors. ${ }^{197}$

What are these actions? One is manipulation of the split notice. The Operator employs the personnel who read the meters in the field that record the actual volumes of production from various wells and the volumes that are delivered to relevant gas plants and pipelines. The Joint-Operators do not. As a result, it is the Operator that provides information to the processing plant Operator regarding volumes, ownership entitlement, and the respective delivery points and purchasers of all gas that it delivers to the plant. The plant Operator then relays that same information on to the operator of the pipeline into which it delivers the

1951990 CAPL, supra note 1, cl. 505(b).

$196 \quad$ See generally Powermax, supra note 28.

197 The Operator may often be reluctant to take some or all of the steps that are available to it, even where they are legitimate, because of "big picture" concerns. The Operator will not always operate all of its lands, and so may sometimes find itself in the position of being a Joint-Operator, both with the JointOperator and with other industry partners. In consideration of that possibility, the Operator may choose not to play all of the cards in its hand. 
processed gas. The pipeline operator uses that information to make deliveries to respective purchasers and relays the information on to those purchasers. In reliance on this split information, the gas purchaser determines what cheques to write to whom. The end result is that, although the Joint-Operator is delivering its own gas to its own purchaser and should be paid directly, the amount that it is in fact paid is based on information provided to the entire system by the Operator. The potential for abuse is obvious: if the Operator provides information that directs the Joint-Operator's share of production revenues into the Operator's hands, the Operator has manipulated events so that it is now in a position to offset that revenue against debts owed to it by the Joint-Operator.

Obviously, this practice is not authorized by cl. 505 of the 1990 CAPL. On the surface, it raises a number of potential, if slow moving, dangers for the Operator in terms of its accountability to the Joint-Operator. The interesting thing, or, depending on your perspective, the frustrating thing, is that it can be difficult for the Joint-Operator to do anything about this fast enough to have much practical effect. It is also interesting to consider the legal characterization of the split notice. What obligation does the gas purchaser owe to the JointOperator in relation to the split notice? What right does it have to rely on it, and what is the foundation of those rights? More specifically, does the purchaser have any duty to verify the accuracy or legitimacy of a split notice? Does it have any duty to pay heed to a complaint or notification by the Joint-Operator that information contained in a split notice is inaccurate? In short, what are the mutual rights and obligations of the three parties involved — the JointOperator, Operator, and gas purchaser?

When we review typical gas sales agreements, it is difficult to find a specific reference to the split notice or to the gas buyer's right to rely on information received from a third party (the Operator) as to volumes delivered. Curiously, although both gas purchase and processing contracts require the purchaser (or Operator, as the case may be) to purchase or process all of the gas delivered to within a particular definition, the contracts do not address how the purchaser or Processor is to receive information as to exactly what volumes are delivered by whom, or as to what duties and obligations it owes to a particular seller or producer to verify that information. Some gas buyers appear to be prepared to ignore a notification from a JointOperator that it disputes a sudden change in split notice particulars, and will hold the gas buyer responsible for payments it makes to the wrong party. The gas buyers' position may be that they receive information as to volumes delivered and the party entitled to payment from the pipeline Operator, who receives it from the plant Operator, who receives it from the field Operator. The message might be that this is the way this is done - the Joint-Operator knows how the system works, and the gas buyer is just following orders and owes no duty to the Joint-Operator in this respect. Gas buyers might also consider themselves protected by representations and warranties of gas ownership provided to them by the Operator under their mutual gas sales contract.

We have been unable to locate any express contractual authorization given by a JointOperator that allows the Operator to conduct the field meter measuring, to deliver split notice information to appropriate parties, or that allows a facility or pipeline Operator, or gas buyer, to rely on information considering the Joint-Operator's volumes that is provided by a third party Operator. The very general 1990 CAPL delegation of "the management of the exploration, development and operation of the joint lands and the construction, installation 
and operation of any production facilities for the joint account” to the Operator might contemplate at least some of this. ${ }^{198}$

Are all of those authorizations given implicitly by industry custom or by conduct? If so, are they not revocable by notice? A Joint-Operator might be well served by an express provision in its gas sales contract to the effect that, if the seller gives written notice to the gas purchaser that the latter is no longer entitled to rely on information received from a third party Operator as to volumes delivered, the gas purchasers must respect that notice and, at a minimum, withhold further payments to the third party Operator until the matter is clarified to the satisfaction of all parties.

\section{INTERFERENCE WITH THE RIGHT TO TAKE IN KIND}

A complementary and questionable Operator device is to purport to terminate the JointOperator's right to take in kind, thereby assuming control over the Joint-Operator's share of production. There is nothing in cl. 505 or elsewhere in the 1990 CAPL that says that a JointOperator loses its right to take in kind when it falls into arrears. In our view, Operators that take this step without clear authorization under art. VI of the 1990 CAPL are breaching the 1990 CAPL, but we have seen cases in which Operators have gone so far as to advise third party gas buyers to cancel contracts and cease taking deliveries from the Joint-Operator because the Operator is no longer allowing that Joint-Operator to take in kind.

The fiduciary requirements of the Operator discussed in Powermax and elsewhere seem to apply with the effect that the Operator may be held liable for losses of the Joint-Operator resulting from an improper manipulation of affairs that enables the Operator to seize the Joint-Operator's production without following the procedures laid out in cl. 505 of the 1990 CAPL.

We also note that cl. 606 of the 1990 CAPL provides the Joint-Operator with a lien exercisable where the Operator fails to remit proceeds of production.

\section{Other Practical Observations}

1. The alert Operator has an opportunity to reduce or avoid the need to rely on cl. 505 of the 1990 CAPL by acting before a Joint-Operator's debts have risen to problem levels by taking advantage of cls. 503(a) and (b). Clause 503(a) allows the Operator to "require that individual Joint-Operator to secure payment of its proportionate share of all costs to be incurred for the joint account” pursuant to a particular AFE “in a manner satisfactory to the Operator." ${ }^{\prime 199}$ The clause describes the requirements of an irrevocable standby letter of credit, but does not limit security to this form. As an alternative to cl. 503(a) but almost certainly not by way of an addition to it, cl. 503(b) of the 1990 CAPL allows the Operator to require "each Joint-Operator to advance its proportionate share of all costs to be incurred for the joint account, subject to 
Subclause (a) of this Clause.”200 This is commonly called the "cash call.” However, this approach may not be practical in all situations given time constraints caused by rig availability, lease compliance issues, or competing demands on administrative time. The valid, effective, and efficient exercising of rights under cl. 503 of the 1990 $C A P L$ requires a degree of diligence and planning on the part of the Operator. Clause 503(b) also seems to require that the Operator cash call all Joint-Operators if it is going to make a cash call on any one of them. This may cause discontent among working interest partners.

An Operator cannot validly effect a cash call without taking some prerequisite steps. It must, not earlier than 30 days prior to the first day of the calendar month in which it wishes the cash call to be paid, submit to each Joint-Operator "an itemized written estimate of the costs which are expected to be paid by the Operator for the joint account hereunder in that calendar month, together with a request for payment by each Joint-Operator of its proportionate share thereof, insofar as such amount is not secured by Subclause (a) of this clause.”201 The Joint-Operator has 20 days after its receipt of such a notice to pay its share before it is in default. Interestingly, the lien under cl. 505(a) of the 1990 CAPL does not appear to secure the Joint-Operator's obligation to pay under cl. 503. Clause 505 secures only amounts that have been incurred "for the joint account."

Clause 503 seems somewhat weak in the circumstance in which a Joint-Operator fails to comply with a valid cl. 503 demand. The Operator does not appear to have the right to cash call the others for immediate payment of the shortfall, although it can eventually look to them under cl. 506 of the 1990 CAPL. Apart from that ability, the Operator's last line of defence remains its rights under the CAPL lien, which is triggered once a payment has been incurred for the joint account has been invoiced to the joint operator and remains unpaid after 30 days (i.e., probably after a cost relating to an operation has been incurred). Finally, note that cl. 503 is restricted to amounts owing under an approved AFE. Therefore both cls. 503(a) and (b) address capital costs only and not operating costs. However, cl. 105 of the 1996 PASC provides the Operator with a similar ability to call for advance payment of "an approved forecast of expenditures for Operations and Maintenance for a year.”"202

2. Some Operators may also view cl. 506 of the 1990 CAPL as providing alternate or backup security to them. Clause 506 provides that if the Operator has not received full payment of a Joint-Operator's share of the costs and expenses of joint operations within three months following the date the payment was due, each other JointOperator must pay its proportionate share of the defaulted amount. Upon making its proportionate share of payment, each such contributor is proportionately subrogated to the Operator's rights under cl. 505 of the 1990 CAPL. Thus, to the extent that other Joint-Operators did not pay their proportionate share of another Joint-Operator's arrears, they are in default and subject to the Operator's lien attaching to their 
interests, and to the extent that they do contribute, they reduce and share in the Operator's exposure.

3. Under cl. 402 of the 1990 CAPL, each of the Joint-Operators indemnifies and saves harmless the Operator from losses and expenses that may be attributable to or arise out of any act or omission of the Operator, subject only to gross negligence or wilful misconduct under cl. 401(b). That indemnification is not secured by the CAPL lien in cl. 505. Clause 505 secures only "costs and expenses incurred by the Operator for the joint account." 203 To our knowledge, no reported decision has addressed whether the Operator's failure to register its Operator's lien constitutes gross negligence or a breach of fiduciary duties to the other Joint-Operators who must share in the risk caused by that failure.

4. It is clear that a single financing statement registered under the PPSA can suffice to perfect an Operator's lien under the PPSA, notwithstanding that Operators continuously advance and recover money to and from the other Joint-Operators, and that one Operator may have several different agreements with a particular JointOperator. Section 14 of the PPSA recognizes that single security agreements may provide for future advances, and ss. 43(4) and (5) provide that a financing statement can be registered before any security agreement is entered into and that the registration may relate to more than one security agreement. However, practical considerations might complicate this issue. Joint-Operators and their banks can be alarmed by the registration of a sweeping financing statement that refers to future advances when no amounts are in arrears and we have experienced cases in which they have demanded that the financing statement be discharged when the arrears are paid, or as a term of a negotiated settlement to a dispute. However, once the necessity of registering and its real impact is explained to them, lenders and Joint-Operators are generally reassured. Registration of the Operator's lien does not necessarily mean that the Joint-Operator is in arrears, any more than perfection of bank security does. The Operator's lien attaches only to the Joint-Operator's interests under certain operating procedures and those assets may not be critical to the overall affairs of Joint-Operator. Also, the Operator's lien protects the Operator only in respect of amounts owing to the Operator. In many cases, that will be a relatively small amount, not significant to the Joint-Operator's other secured creditors. Also, the registration has no impact whatsoever on prior registrations by secured lenders. Negative covenants in the JointOperator's loan agreements might provide for a default in the event that the liens were enforced, but it is unlikely that a negative covenant would prevent liens from being perfected.

5. Attention must be paid to a number of mechanical details. Any registration must be effected in accordance with the registration requirements in the governing legislation in order to be valid. Thereafter, such registrations must be diligently maintained in order to benefit from the various priority provisions in the governing acts that we have discussed above. Secured parties must comply with the service requirements set out in each of the governing acts. When the Operator assigns its interest, or a new 
Operator is appointed, the registered security interest or caveat should be transferred along with the underlying interest. In the case of a registration under the PPSA, the financing statement may need to be renewed from time to time, depending on the time period selected at registration, and updated with any assignment of the JointOperator's interest in order to preserve priority. Keep in mind that the same holds true for prior registrations; the Operator may wish to examine all of the registration details and mechanics of prior conflicting security registrations, as it may find a basis to challenge the entitlement of such security to statutory priority.

6. The recent Alberta Court of Appeal decision in BG International ${ }^{204}$ may be of some application in very limited circumstances and of assistance to a Joint-Operator whose Operator may be insolvent. By way of background, BG International Ltd. (BG), Canadian Superior Energy Inc. (Canadian Superior), and Challenger Energy Corp. jointly owned an offshore operation off the coast of Trinidad and Tobago. The parties had agreed to use the standard form the Association of International Petroleum Negotiators (AIPN) Joint Operating Agreement ${ }^{205}$ to govern operations, with Canadian Superior as Operator and Alberta law to apply. The parties had undertaken a drilling operation involving an offshore drilling rig procured under contract from Maersk. It was alleged that Challenger defaulted on its payment obligations in respect of the operation to Canadian Superior, and that Canadian Superior in turn defaulted on payments for the joint account owed to Maersk.

Despite the fact that the AIPN Agreement had express and elaborate mechanisms for dealing with this sort of situation, BG obtained an interlocutory order placing the assets and operations in an interim receivership pursuant to s. 13(2) of the Judicature Act, which allows for the appointment of a receiver when it is "just or convenient" to do so. ${ }^{206}$ The grounds for the order, as BG argued, were that the parties faced the "emergency"207 of Maersk removing the rig before operations were completed unless the overdue amount was paid. Although BG was obligated under the AIPN Agreement to pay such amount to Canadian Superior, because of Canadian Superior's financial condition, BG was concerned that if it paid the outstanding amount to Canadian Superior the money might not reach Maersk. BG had also commenced proceedings in accordance with the AIPN Agreement to replace Canadian Superior as the Operator, but argued that the process set out in the AIPN Agreement was too slow to avoid the impending rig removal. The receivership order effectively overrode the contractual rights and obligations of the parties under the AIPN Agreement, as well as the underlying secured creditor rights and priorities. Although the AIPN Agreement provides that parties have a right to seek an interim receivership in certain circumstances, and there is no equivalent in the $1990 \mathrm{CAPL}$, we query whether a 
Joint-Operator might be able to obtain such relief on equitable grounds where a suitable emergency exists or the "just or convenient" test can be met. ${ }^{208}$

7. As between the Operator and the Joint-Operator, the Operator's lien is effective regardless of registration. In the event of the bankruptcy of the Joint-Operator and with respect to the Joint-Operator's real property, it appears that the trustee in bankruptcy takes such property subject to the Operator's lien even if it is unregistered. ${ }^{209}$

8. In a CCAA scenario, one of the first things that an Operator should do is to obtain and read a copy of the CCAA court order. The CCAA grants wide discretion to the court, and these orders vary from case to case. Generally, the orders contain whatever terms and conditions the applicant can convince the judge to award in that case. The Operator should confirm that the monitor appointed by the order is directed to pay to the Operator all joint account costs that are incurred after the order is granted. If the Operator is not satisfied that it is protected going forward, it might want to consider what steps are available to it to manage ongoing or expanding exposure to the insolvent Joint-Operator, including negotiations, court applications, and contractual remedies and termination. In some cases, the Operator may even need to consider taking the extreme step of challenging the validity of the lender's security.

9. Where circumstances are such that an Operator clearly ranks behind a secured creditor, the Operator still might find a lifeline in the principle of marshalling. That principle may entitle the Operator to require the prior secured lender to realize against all its collateral in a manner that will not only discharge the Joint-Operator's debt to the prior secured lender, but also provide an opportunity for the Operator, as subordinate creditor, to recover some or all of the debt owing to it. ${ }^{210}$

10. Irrespective of the rights and remedies afforded to the Operator in the $1990 \mathrm{CAPL}$ (and absent further indemnities provided in a given head agreement), the Operator may be exposed to liabilities to third parties which arise after the Operating Procedure has terminated without indemnity from the Joint-Operators as provided for in the 1990 CAPL ${ }^{211}$ Assuming the most common scenario, where the Operator is also the holder of the license issued by the applicable regulatory authority, this possibility should be of concern to Operators in light of the marked and continuing increase in environmental regulation in recent years. Environmental orders can be issued years after abandonment. In the $2007 C A P L,{ }^{212}$ efforts have been made to extend the indemnities against such liabilities. the Joint-Operators may subrogate into and enforce the CAPL lien against the defaulting Operator. See BIA, supra note 46 , ss. $70-84$.

See generally Manzer \& Ruda, supra note 171.

See 1990 CAPL, supra note 1, cl. 2901.

Supra note 1, cls. 1.01, 1.14. 


\section{Processors’' LiENS}

We have only enough room to make a few brief observations concerning Processors' liens, as distinct from Operators’ liens.

As a general frame of reference, we refer you to the Petroleum Joint Venture Association (PJVA) 2005 (2008 Revised) model Gas Handling Agreement. ${ }^{213}$ We will use it as a representative form of Processor's lien. Clause 706 begins as follows:

\footnotetext{
Producer, in order to secure any indebtedness to Operator under this Agreement, hereby gives and grants to Operator a first lien and charge on Producer Inlet Substances and Producer Outlet Substances, to secure payment of any handling charge or other amount payable to Operator by Producer. ${ }^{214}$
}

Clause 706 then goes on to list a number of remedies that are available to the Operator if the Producer "defaults in payment of its bills and such defaults shall continue for five (5) Days after receipt of written demand from Operator.” It provides that this list does not limit “Operator's other rights in this Agreement or otherwise held at law or in equity."215

It is apparent that this Processor's lien provision has been modelled after the CAPL Operator's lien, with modifications to adjust to the different circumstances at play in a gas handling or processing agreement. The most significant difference between the Processor's lien and the Operator's lien is that the Processor's lien attaches to personal property only, and to only one type of personal property: gas that is delivered to the subject plant (and the substances that are recovered from that gas). None of the complications relating to real property rights or other types of personal property that arise in connection with Operators' liens need be considered.

As brief commentary on the legal and practical considerations that pertain to the enforcement and priority of Processors' liens, we offer the following:

- $\quad$ The cure period in cl. 706 of the Gas Handling Agreement is five days as opposed to 30 days in the 1990 CAPL. ${ }^{216}$

- $\quad$ Pursuant to paragraph 706(b) of the Gas Handling Agreement, the Operator has the right to "discontinue handling of Producer Inlet Substances until such time as the indebtedness is paid." ${ }^{217}$ Under the 1990 CAPL, the Operator does not have the ability to withhold all services. Discontinuation of service may not result directly in the recovery of arrears, but it will certainly stop arrears from growing. How might that right of discontinuation be affected by any particular Producer's CCAA stay order?

- Clause 706(c) of the Gas Handling Agreement provides for a right of set-off, modelled closely on the corresponding term in the 1990 CAPL, and so our discussion

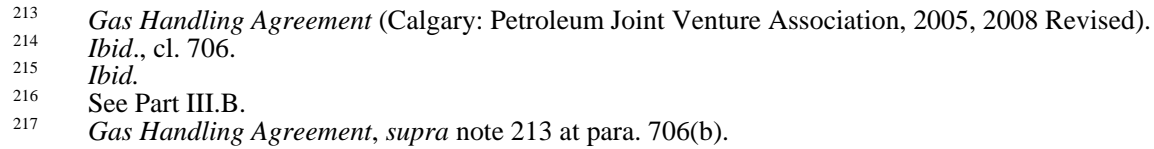


of the CAPL set-off right, as well as other legal and equitable set-off rights that might apply outside of the contract, applies. ${ }^{218}$ Although common law and equitable principles no longer play a significant role in most incidents of lien enforcement or priority issues, when we turn to the procedural, self-help remedy of set-off, several common law and equitable principles, including those pertaining to the effect of notice of prior assignments, are still applicable.

- Set-off is available to a creditor only when the creditor owes money to his debtor. From the Processor's perspective, while the producer may owe money to the Processor, it will not always be the case that the Processor also owes the producer a debt under the processing agreement. In some circumstances, the Processor will also be the producer's “Operator” under an operating agreement relating to the same lands, and the Joint-Operator/producer may owe money under that agreement, but cl. 706(c) of the PJVA Agreement does not provide a contractual right to set-off debts under a separate operating agreement. The Processor/Operator may wish to consider its legal and equitable rights to set-off those related debts in those circumstances.

- Clause 706(e) of the Gas Handling Agreement includes language very similar to the assignment of proceeds provided in 505(b)(v) of the 1990 CAPL. Our discussion above relating to the assignment of debts. ${ }^{219}$

- For practical purposes, the most important Processor's lien remedy may be the right to take the producer's gas sale proceeds. There are two ways in which the Processor may get at that revenue: the Processor can enforce the assignment of the proceeds of sales under the producer's gas sales contract under cl. 706(e) of the Gas Handling Agreement, or it can take and sell the Producer Outlet Substances itself and keep the proceeds under cl. 706(f). ${ }^{220}$ As with Operators' liens, these seem to work at a practical level until one introduces the complexity of a priority dispute, or a producer insolvency. At that point, the gas Processor's lien, and its rights to this revenue, may become useless if those rights are subordinated by applicable priority rules to conflicting rights held by other creditors.

- Obviously, the Processor will have difficulty seizing gas once it has left the plant. However, the wording of cl. 706 of the Gas Handling Agreement extends the lien to the proceeds of sale of the "Producer Inlet Substances" or "Producer Outlet Substances." 221 Section 28 of the PPSA protects the Processor's security interest in those proceeds, particularly if it is perfected under the PPSA. ${ }^{22}$

- Because the Processor's lien deals exclusively with personal property, the PPSA is the primary, and almost exclusive, reference point for the rules that tell us how this lien and charge will be received and treated in court, and how its priority relative to other 
security interests will be determined. The foregoing discussions relating to the PPSA are applicable, including our questions concerning whether s. 32 of the PPSA should protect gas Processors' liens even when they are not registered under the PPSA. ${ }^{223}$

- In practice, gas Processors' liens are not perfected by registration under the PPSA any more often than Operator's liens are. In Blue Range, ${ }^{224}$ Romaine, J. addressed a lien created under a gathering and processing agreement. Justice Romaine held that the lien provision created a valid lien and charge on the debtor's gas, and that such lien and charge was a "security interest" in personal property and was therefore governed by the PPSA and subject to the residual priority scheme set out in s. $35 .^{225}$ It followed directly that because this security interest had not been perfected under the PPSA by registration of a financing statement, it could not take priority over security interests that were perfected in accordance with the PPSA.

\section{CONCLUSIONS AND RECOMMENDATIONS}

As Corbett states, the remedies given to an Operator under cl. 505(b) of the 1990 CAPL are relatively extensive. ${ }^{226}$ In our experience, however, the usefulness of the legal and practical remedies available to the Operator - either expressly pursuant to cl. 505(b) of the 1990 CAPL, or by common law independently of that clause - varies with the facts. The importance of registering an Operator's lien in order to preserve the enforceability and priority of the Operator's rights will also vary according to the facts, but will certainly increase if the insolvency of the Joint-Operator is involved.

A close examination of the details of the CAPL lien and the wording and procedures required under the various registration statutes that apply reveals that these do not always interact smoothly. Further adaptation of the wording of cl. 505(b) of the 1990 CAPL might be called for, with an eye to the requirements of the PPSA. Some adaptations to cl. 505(b) in recognition of current industry practices might also be useful, particularly with reference to cl. 505(b)(vi) of the 1990 CAPL. As noted above, cl. 505(b) (including cl. 505(b)(vi) ${ }^{227}$ ) has received significant attention in the 2007 CAPL.

In order to make the most effective and timely use of the remedies under the CAPL lien, Operators should pay close attention to the financial strength of their Joint-Operators and to the status of their accounts payable. The sooner a notice of default is served, the sooner the Operator can commence enforcement of the remedies provided to it in cls. 505(b)(iii)-(vi) of the 1990 CAPL. ${ }^{228}$

In order to at least protect against loss to other unsecured or unregistered creditors, registration of the Operator's lien against personal and real property is prudent where there are any signs of financial weakness in a particular Joint-Operator. Operators might also want

See Parts V.B.3, V.B.3.a.

Blue Range, supra note 153.

Ibid.

See Corbett, supra note 12 at 27-29.

See Part V.B.3.b.

See Part IV.A.1. 
to register in respect of any new or insubstantial Joint-Operator as soon as the operating agreement is signed, or, in some cases, even consider refusing to sign with a Joint-Operator that has granted prior registered security and is a poor credit risk.

Lenders to Operators might consider requiring Operators to protect their Operators’ liens by registration.

However, registration is not without costs, and is not always practical or necessary. For an Operator that has dozens of joint venture partners under hundreds of agreements, with assignments to new Joint-Operators taking place on a regular basis, a policy of full registration would be impractical. We are reluctant to recommend widespread registration of Operators' liens against all Joint-Operators in all circumstances, yet non-registration involves risk. Is this situation of risk fair and necessary?

The fundamental importance of the Operator in the industry is obvious, and the existence and importance of the Operator's lien is known to every lender, investor, and service provider. All the players know that the Operator will be advancing its own money for the benefit of all stakeholders. It seems reasonable to assume that players would all agree that the Operator should at least have the benefit of its lien should it not be repaid. Nevertheless, the law requires the Operator to register every such lien in order to protect it (subject to the MMA). An Operator's lien or a Processor's lien will lose any priority contest with a secured, registered lender, regardless of which interest arises first in time, regardless of notice, and, to date, regardless of considerations of practicality, commercial reality, or industry custom - unless the Operator or Processor registers (and even then, the lender may register before the Operator or Processor does). It does not seem necessary or equitable to require this of all Operators. Section 32 of the PPSA might have provided a solution, by providing an exemption from the need to register, but the courts have decided otherwise ${ }^{229}$ and s. 32 could not address $L T A$ and $M M A$ issues in any event. ${ }^{230}$

Section $6(2)$ of the $B L A$ was added to the $B L A$ to specifically address a commercial reality of oil and gas industry practices so as to ensure that the purposes of the $B L A$ were achieved with respect to that reality. ${ }^{231}$ We suggest that it is worth considering the addition of a similar, industry-specific provision to the LPA, PPSA, LTA, and MMA to provide that all normal course Operators' (and Processors') liens are exempt from the need to register and from the other statutory priority rules attached to registration, and have priority over all other security interests, whether perfected or unperfected, and whether acquired prior or subsequent to the date of the agreement pursuant to which the lien is created.

Statutory recognition of Operators' liens would not be unprecedented. ${ }^{232}$ But until the law is changed, Operators would be well advised to give more consideration to protecting their contractual security interests by registering them than is currently the common practice in the industry. 